NASA Technical Memorandum 87112

1232

\title{
An Experimental Investigation of Reducing Advanced Turboprop Cabin Noise by Wing Shielding
}

James H. Dittmar

Lewis Research Center

Cleveland, Ohio

(NASA-TM-87112) AN EXEERIMENTAI

INVESTIGATION OF EEDUCING ADVANCED TURBOPROP

CABIN NOISE BY KING SHIELDING (NASA) $37 \mathrm{p}$

HC AO3/MF AO 1
N86-25218

Unclas

G3/71:43047

Prepared for the

Tenth Aeroacoustics Conference

sponsored by the American Institute of Aeronautics and Astronautics

Seattle, Washington, July 9-11, 1986

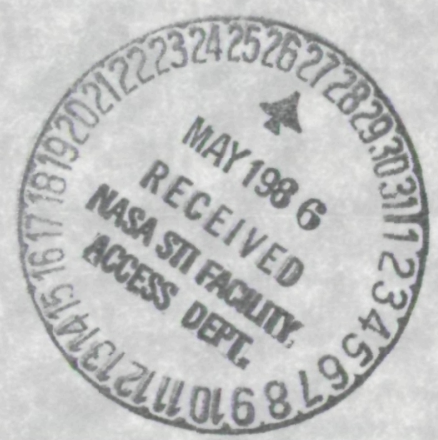


AN EXPERIMENTAL INVESTIGATION OF REDUCING AOVANCËD TURBOPROP CABIN NOISE BY WING SHIELDING

\author{
James H. Dittmar \\ National Aeronautics and Space Administration \\ Lewis Research Center \\ Cleveland, Onio 44135
}

\section{ADstract}

An experimental investigation was undertaken to determine if wing shielding could reduce the noise impacting the fuselage of an advanced turDoprop airplane. Four wings were tested benind two eight-bladed propeller models. Significant shielding of the propeller noise was observed and a particular wing-propeller geometry was identified to provide the most snielding. Specifically, an up-inboard rotation would be needed for a lowwing airplane and a down-inooard rotation for a nigh-wing airplane.

As the axial Mach number was increased, the position where the shielding starts moved farther downstream. This shift in the start of shielding was roughly a straight line with respect to Mach number between $M=0.7$ and $M=0.8$. At $M=0.85$ the start of shielding does not shift any farther downstream. A simple barrier noisereduction model gave the same trends with transducer position as did the data, and, if corrected for Mach number shift, the model might be used to provide estimates of the wing shielding. Besides providing a barrier to the noise reaching the shielded area, the wing also reflects some of the noise back onto the unshielded area. This can make the noise difference between the unshielded and shielded areas of the fuselage larger than would be expected by simple wing shielding.

\section{Introduction}

Advanced turboprop-powered aircraft have potential for significant fuel savings over equivalent technology turbofan-powered aircraft. One of the requirements to implement this potential is a cabin environment acceptable to the airline passenger. At present the passenger cabin noise level at cruise poses a possible obstacle to the acceptance of these aircraft and is an area.under investigation. The noise from this type of propeller and the severity of the noise impacting upon the airplane fuselage is described in Refs. 1 to 4 . One way to reduce the noise level is to configure the airplane such that the wing blocks the propeller noise from reaching the cabin.

The feasibility of shielding the airplane fuselage from the shock waves emanating from supersonic tip speed propellers was investigated in Ref. 5. In Ref. 5, the suction-surface shock wave was assumed to be the wave most likely to impact the fuselage, and the geometric relationships were developed to nave the wing block the shock as shown in Fig. 1(a). The pressure field associated with these supersonic propellers is, nowever, strongest on the pressure side of the olade as gescribed in Ref. 6 and shown in Fig. 1(b). In order to block this loading noise from striking the fuselage, the wing is positioned in opposite relationsnip with respect to the propeller rotation from that required to block the suction-surface shock wave (Fig. 1(b)).
In order to determine (1) which of these mechanisms controlled the maximum noise levels impacting the fuselage and (2) how much of the noise could be blocked by a wing, a set of experiments was performed. These experiments were performed with two advanced eight-bladed propeller models, SR-2 and SR-3, and four simulated swept wings with different sweep angles. This paper presents the results of these experiments performed in the NASA Lewis $8-$ by 6 -Foot Wind Tunnel.

\section{Apparatus and Procedure}

\section{Propellers}

Two supersonic helical tip speed propeller models were used in these experiments. The SR-2 is a straight-bladed propeller and the SR-3 propeller has swept blades, each has eight blades. Table 1 shows propeller characteristics and more information on these propeller models can be found in Ref. 7. Photographs of these propellers in the 8- by 6-Wind Tunnel are found in Figs. 2(a) and (b).

The straight-bladed SR-2 propeller (Fig. 2(a)) was indicated in Ref. 8 as having strong leading and tailing edge shocks, while the swept SR-3 propeller (Fig. 2(b)) had only relatively weak trailing edge shocks. Both of these propellers were tested, since the SR-2 is the propeller model most likely to exhioit snock wave shielding (Fig. $1(\mathrm{a})$ ), and the SR-3 is the model most likely to exhibit shielding of the pressure surface sound wave (Fig. $1(b))$.

Wings

Four wing, geometries were tested with each of the propellers. The method in Ref. 5 was used to calculate the wing geometry needed to block the shocks from these propellers. In Ref. 5, a hypothetical airplane was outlined and a wing sweep of $45^{\circ}$ was determined to be sufficient to block the shocks. In these wind tunnel experiments the propeller is proportionally closer to the tunnel ceiling than the propellers on the example airplane and the necessary wing sweep angle is greater. The geometry calculated to block the shocks in the wind tunnel has the leading edge of the wing $15.2 \mathrm{~cm}$ ( 6 in.) behind the propeller at the propeller tip and a wing sweep of $55^{\circ}$. This wing sweep is larger than would normally be used on an airplane, but was required for the tunnel geometry. To investigate the effect of wing sweep angle, two other angles of $60^{\circ}$ and $50^{\circ}$ were chosen. Both of these wings were also designed to pass through a point $15.2 \mathrm{~cm}$ (6 in.) behind the propeller at the tip. In addition, to investigate the variation of propeller wing distance, a wing at the $55^{\circ}$ angle was also designed to pass through a point $50.8 \mathrm{~cm}$ (20 in.) behind the propeller at the tip. The wings were of flat plate construction and faired into the propeller test-rig support strut as shown in Fig. 3 . 
The SR-2 and SR-3 propellers have the trailing edge at different positions relative to the propeller plane (see Fig. 2, Table 1), and therefore require different wing sections for the propellers to have their leading edge $15.2 \mathrm{~cm}$ ( 6 in.) benind the propeller at the tip. To accomplish this, the SR-3 wing sections should have been translated $0.1 \mathrm{~cm}(2.4$ in.) downstream, but actually were translated only $3.6 \mathrm{~cm}$ (1.4 in.) downstream. Therefore, the SR-3 wing sections were actually $2.4 \mathrm{~cm}$ ( 1 in.) closer to the SR-3 propeller than the SR-2 wing sections were to the SR-2 propellers.

The geometries actually tested are shown in Fig. 3. Four wings designated $60^{\circ}, 55^{\circ}$ forward, $50^{\circ}$, and $55^{\circ}$ af.t were tested with each propeller. The $60^{\circ}, 55^{\circ}$-forward, and $50^{\circ}$ wings were $15.2 \mathrm{~cm}$ (6 in.) benind the SR-2 propeller at the tip and $12.7 \mathrm{~cm}$ (5 in.) behind the SR-3.propeller. (See dimension $A$ of $\left.F i g .3^{3}\right)$ The $55^{\circ}$-aft wing was $50.8 \mathrm{~cm}(20 \mathrm{in.})$ behind the SR-2 propeller at the tip and $48.3 \mathrm{~cm}$ (19 in.) behind the SR-3 propeller. Figure 3 also shows the positions on the ceiling where the leading edge of the wing intersects the ceiling. Photographs of the $55^{\circ}$-forward wing are shown with the SR-2 and SR-3 propellers in Figs. $4(a)$ and $4(b)$, respectively.

These wing sections were designed specifically to olock the shock waves from the propeller supersonic tips. It was not deemed necessary to design a separate wing section specifically to olock the propeller loading noise, since it was felt that tnese wings would perform that function as well; the difference being that the wing shielding woula occur on the opposite side of the wing. Therefore, the ceiling of the wind tunne? (which represents the airplane fuselage) was instrumented on both sides of the wing so as to measure shock or pressure wave shielding. This instrumentation is described in the following section.

\section{Pressure Transducers}

Thirty-two pressure transducers were installed flush in the wind tunnel ceiling through the tunnel bleed holes. The transducers were configured in four rows of eight with two rows on each side of the tunnel centerline where the wing is placed. The layout is seen in Fig. 5. The transducers in the rows closest to the ceiling centerline were numbered from 1 (farthest forward) to 8 (fartnest aft). The subscript $N$ indicates the row on the north side of the centerline, and $S$ indicates the row on the south side. These rows were $21.44 \mathrm{~cm}(8.44 \mathrm{in.})$ from the ceiling centerline. The outer rows were numbered from 9 to 16, again with $N$ (north) and $S$ (south) subscripts. The outer rows were $31.6 \mathrm{~cm}$ (12.44 in.) from the centerline. The plugs which nold these transducers can be seen in Fig. 4 .

The locations of these transducers in the $Y, Z$-coordinate system of Fig. 5 are listed in Table 2. The angular location of these transaucers with respect to the propeller centerline is included in Table 2 and was calculated with Doth the $Y$ and $Z$ coordinates.

The close rows of transducers are about one-third of a propeller diameter and the outer rows about one-half of a propeller diameter from the ceiling centerline. As seen in Fig. 4, there were other rows of bleed holes, farther from the centerline, which could have been used for transducer locations. A concern for tunnel wall reflections led to the choice of the rows closest to the tunnel centerline. Reference 9 used a two-dimensional argument to indicate why acoustic measurements of advanced propellers were possible in this acoustically untreated wind tunnel. Primarily, the peak noise reflected from the opposite wall of the wind tunnel is swept downstream by the axial flow in the tunnel and does not impact the transducer array. This two-dimensional argument of Ref. 9 becomes less representative of the reflected wave pattern the closer the measurement location approaches a wind tunnel corner. Therefore, the two rows closest to the ceiling centerline, and, thereby, farthest from the tunnel corners, were chosen.

\section{Operating Conditions and Data Reduction}

The wind tunnel was operated at $0.6,0.7$, $0.75,0.80$, and 0.85 axial Mach numbers. The propellers were operated at an advance ratio of 3.06 at each of the tunnel Mach numbers. The propeller blade setting angle was nominally the design angle for each propeller, $59^{\circ}$ for $S R-2$ and $61.3^{8}$ for SR-3, measured at the 3/4-radius location. Data were taken for four wing configurations and with the wing absent for both propellers.

A 1 min sample of acoustic data was recorded on analog magnetic tape for each test condition and digitized off line for processing. A sample length equivalent to 1000 revolutions of the propeller was used in this digitizing. The digitized data were then processed into narrow-band spectra and the average sound-pressure level of the fundamental tone was read from these plots.

\section{Results and Discussion}

\section{Data Suitability}

The data taken at the close positions, 1 through 8 , north and south, were generaliy well behaved and indicated a significant amount of wing shielding. It was felt that this represented an acceptable set of data. However, the data at the outer transducer positions, 9 through 16 , north and south, did not appear well behaved. These data showed noise reductions on both sides of the wing and it appeared to be suffering from tunnel reflections when the wing was installed. The outer sets of data were judged to be unacceptable and only the data from the close positions, 1 through 8, north and south, were used in this report.

\section{General Wing Shielding}

The blade passing tone data obtained witn the close transducers are listed in Tables 3 and 4 . A representative sample of the wing shielding data can be seen in Figs. 6 and 7 . Figure 6 contains the SR-2 blade passing tone data, and Fig. 7 contains the SR-3 data for the $55^{\circ}$-forward wing configuration.

Data without the wing, for both the north and south side transducers are also shown. Each of the figures shows (a) at $M=0.6$, (b) at 
$M=0.7,(c)$ at $M=0.75$, (d) at $M=0.8$, and (e) at $M=0.85$. In general these data are similar to the data taken with the $50^{\circ}$ - and $60^{\circ}$-wing sections also: The Dlade passing tone data taken with tire $55^{\circ}$-aft wing had substantially the same trends, but it nad some spatial differences that will be discussed later. At some of the locations the data are missing pecause of a faulty transducer or ada channel. At the forward positions of the $M=0.85$ cases the tone was not shown since it was below the tunnel broad-band noise level.

Comparisons were made between the wing and no-wing data, and, in general, the blade passing tone data of Figs. 6 and 7 show that the wing reduces the noise on the north side of the wing while the noise on the south side increases slightly. With the direction of rotation indicated in Fig. 5, the data indicates that the wing is primarily shielding the fuselage from the propeller pressure-surface sound wave and not the shock wave. Some shielding of the shock wave may be present, possibly seen at the three most forward positions for $M=0.75$ on the southside (Figs. $b(c)$ and $7(\mathrm{c})$ ). However, even if this is shock-wave shielding, the initial levels are so low compared with the peak that it is not significant compared with the shielding of the pressuresurface sound. This pressure-wave shielding is observed on both of the propellers and indicates specific geometrics needed to acnieve the shielding on an airplane. In particular, for a highwing airplane, this fuselage snielding requires a down-inooard rotation (Fig. I(b)) or, for a lowwing airplane, an up-inboard rotation.

In Figs. 6 and 7 the amount of shielding is significant. As much as a 16-dB difference was observed between the no-wing and $55^{\circ}$-forward wing configurations ( $S R-2, M=0.75$, at position 7 ). This was approximately the peak noise location for this propeller, so the reduction is significant in quieting the airplane interior.

The snielding increases farther aft as seen for SR-2 at $M=0.75$ (Fig. $6(\mathrm{C})$ ). This is consistent with typical shielding since the transducers close to the leading edge have their noise levels held $h i g h$ by the diffraction around the leading edge. The shielding increases with dis$t$ ances farther away from the leading edge. Some of the test conditions show the amount of shielding decreasing at the most aft transducers. (See, for example, $S R-2, M=0.75$, and $M=0.8$.) The reason for tnis is not known at the present time. The $M=0.6$ data are different than the other ata since they do not show an increase in shielding with farther aft position. It may be as suggested in Ref. 9, that the $M=0.6$ data are being affected by tunnel reflections.

\section{Effect with Axial Mach Number}

A trend with axial Mach numbers appears to exist in the data. As the Mach number is increased for both propellers the angle at which shielding begins moves farther downstream (Figs. 6 and 7).

At an axial Mach number of 0.6 the shielding appears to be at all positions; at $M=0.7$ the first position does not seem to exhibit any shielding but shielding is observed beyond position 2. At $M=0.75$ the snielding is observed benind position 3 and at $M=0.8$ tine snielding is downstream of position 5 . The data at $M=0.85$ shows the shielding mainly occurring downstream of position 5. This may be more easily seen in Fig. 8 and Fig. 9 which show the noise difference between the no-wing and the shielded (north) side for the SR-2 and SR-3 propellers, respectively. The shielding is observed to start $f$ arther downstream as the Mach number is increased as shown in Figs. 6 and 7.

Figures 8 and 9 are used to determine the most likely location for the start of shielding. At most conditions, the start of shielding is shown by the "Zero crossing," but in some cases it is between transducer locations. No shielding is observed at position 1 , but shielding is observed, for example, for $S R-2$ at $M=0.7$, at position 2. The average between the two positions is the most likely location for the start of shielding. These average starting locations are compiled and plotted versus the Mach number at which they occurred (Fig. 10). The $M=0.6$ start is somewhere in front of the first measurement position and is not plotted. The data from $M=0.7,0.75$, and 0.8 show rougnly a straight line relationship for the shift of the start of shielding with Mach number. At $M=0.85$ the start of the snielding does not shift any farther downstream.

\section{Comparison with Barrier Shielding Model}

In Ref. 5 a shielding model taken from Ref. 10 was used to estimate the amount of barrier attenuation possible from wing shielding. This same model, as described below, is used here to estimate the amount of shielding predicted at each transducer location for comparison with the measured data.

The barrier model is for a point source located on one side of a barrier with the receiver on the other side as shown in Fig. 11 , redrawn from Ref. 10. The attenuation (insertion loss) is as follows: :

$$
\begin{gathered}
\text { Attenuation }=20 \log _{10}\left[\frac{\sqrt{2 \pi N}}{\tanh \sqrt{2 \pi N}}\right]+5 \mathrm{~dB} \\
\text { for } N \geqslant-0.2 \\
=0 \text { for } N<-0.2
\end{gathered}
$$

where the Fresnel number,

$$
N= \pm \frac{2}{\lambda}(A+B-d)
$$

and

$\lambda$ sound wave length

d is the straight-line distance between source and receiver, and

$A+B$ is the shortest path length of wave travel over the wall between source and receiver (Fig. 11). 
For the receiver in shadow and bright zones, the signs of positive and negative are used, respectively.

This barrier model is for a straight barrier and was applied to tne swept wing geometry tested nere by using a ray approach. The ray went from tne $3 / 4$ radius of tne propeller to the transducer, and the barrier heignt was calculated in the plane of intersection of the ray with the wing. The details of this approach are shown in the Appendix.

The calculations performed with this model are for zero axial flow and gave approximately the same predictions for the SR-2 and SR-3 propellers and for the different blade passing frequencies tested. These predictions are compared with the measured data for the propellers with. the $55^{\circ}$-forward wing and shown in Figs. $12(\mathrm{a})$ and (b). In these figures the data at $M=0.6$ are not plotted since they have a different characteristic with position than the other data and, as indicated in Ref. 9, may be affected by tunnel reflections. In addition, to make the plots easier to read, only the attenuation from its apparent starting position on back is plotted.

From the comparison, the barrier predictions and the data seem to have the same general-trends. In particular, the amount of attenuation increases with the more aft the position. For both the SR-2 and $S R-3$ propellers, the $M=0.7$ data at the forward positions follows the predicted curve. The $M=0.7$ ata for the SR-3 propeller (Fig. 12(D)) continues to roughly follow the predicted curve at the aft positions while the SR-2 Jata (Fig. 12(a)) fails below the predicted curve. At the farthest aft position, the SR-3 attenuation falls off sharply for the $M=0.7$ curve. This can be seen in the data at other Mach numDers also $(M=0.8$, etc.). The reason for this is not known at this time. Calculations for trailing edge diffraction around the back of the model support are not included here since the edge is so far downstream, but would have to be included in an estimate for an actual airplane wing.

In general, the prediction forms an upper limit on the measured shielding with the higher Mach number curves roughly following the shape of tne noise prediction curve but being shifted downstream by the axial Mach number. An explanation for this shift may be seen in. Fig. 11. If one envisions an air flow downward over the barrier, the diffracted wave $B$ would be swept farther aft and cause the shielding to start at a farther aft position as seen in the data. It appears from these comparisons that the wing is acting similarly to a barrier in shielding the receiver froin the propeller noise, and that the Darrier model corrected for axial Mach number shift might be used to provide rough estimates of the anount of fuselage shielding from a wing.

\section{Effect with Wing Position}

The barrier prediction model previously described was used to predict the effect of the different wing positions on the attenuation. The $50^{\circ}, 55^{\circ}$-forward, and $60^{\circ}$ wing all pass tnrough the same point behind the trailing edge of the propeller at the tip. Therefore, it is only the differences in the amount of sweep which causes the wings to have different positions of leading edge in the plane of the direct wave. The $55^{\circ}$-aft wing was physically located some $35.6 \mathrm{~cm}$ (14 in.) farther downstream.

Figure 13 shows the barrier predictions for the four wing configurations. As can be seen, the $50^{\circ}, 55^{\circ}$-forward, and $60^{\circ}$ wings nave similar barrier attenuation estimates with the $60^{\circ}$ wing starting slightly forward and the $50^{\circ}$ wing starting slightly behind the $55^{\circ}$-forward wing estimate. The $55^{\circ}$ aft wing, shifted $35.6 \mathrm{~cm}$ (14 in.) downstream, nas the start of its attenuation shifted significantly downstream. This effect is shown in the data measured for these different wing positions.

Figures 14 and 15 shows the $S R-2$ and $S R-3$ propeller data at $M=0.75$ for the four wing positions. The $M=0.75$ condition was used since this was where the most complete data was available for both propellers. The $50^{\circ}, 55^{\circ}$-forward, and $60^{\circ}$ wing basically show the same attenuation with the attenuation starting slightly behind the third transducer position. Any differences in the three starting locations are probably masked by data scatter. The $55^{\circ}$-aft wing appears to be showing a different starting point for the attenuation. This is most apparent in the SR-3 data of Fig. 15 which shows the start somewhere behind the forth or fifth position. The SR-2 data at the $55^{\circ}$-aft position does not as clearly start farther aft, but tine attenuations at the fourth and fifth positions are less than those for the $55^{\circ}$-forward wing, for example.

These effects are better seen in Fig. 16 which snows plots of the no-wing and wing differences for the SR-2 and SR-3 propellers at the $55^{\circ}$-forward and $55^{\circ}$-aft wing positions. Here the observation that the $55^{\circ}$-aft shielding starts farther downstream is more clearly seen. The movement of the starting point downstream from $55^{\circ}$-forward to $55^{\circ}$-aft wings is apparent in both Figs. 13 and 16 , even though the starting points are not the same because of the Mach number shift, which is not considered in the analytical estimate. This trend comparison, between the barrier estimate shift (Fig. 13) and the data shift (Fig. 16) with wing position, is further indication that the wing is acting like a simple barrier to the propeller noise and that the barrier model might be used to roughly estimate the wing shielding.

Noise Difference Between Shielded and Unshielded Sides

When a wing is placed between the propeller and the fuselage the wing shielas the fuselage from the propeller noise, and some of that noise is reflected back by the wing to the unshielded side. Tnis reflection process is similar to a ground reflection wherein the direct and reflected waves interact with each other such that there are regions of reinforcement and cancellation. This is seen in the south-side data of Figs. 6 and 7. An example is also seen in the $M=0.7$ data for SR-2 (Fig. 6(b)). Here, there are regions (positions 5 and 6 ) where an in-phase reflection increases the noise when the wing is installed, and regions (positions 7 and 8 ) where an out of phase reflection causes a reduction. 
The overall effect of a ground reflection is a rise in the noise of about $3 \mathrm{~dB}$, but local minima and maxima, caused by the reflections, do occur. This general increase in the shielded side noise can result in larger differences between the shielded sides and unshielded sides than was previously observed for the wing and no-wing comparisons on the same side. An example of raising the peak noise difference is shown in Fig. 17 which plots the SR-3 data at $M=0.7$. As can be seen, the peak difference between unshielded and shielded sides at position 6 is larger than the no-wing minus wing difference. In other words, the presence of the wing can not only lower the noise on the shielded side but may also raise the peak noise on the unsnielded side.

\section{Concluding Remarks}

The possibility of reducing advanced turboprop cabin noise with wing shielding was investigated. Four swept wings, designated $50^{\circ}$, $55^{\circ}$-forward, $60^{\circ}$, and $55^{\circ}$-aft, were tested with models of the SR-2 and SR-3 propellers. The noise was measured on the ceiling of the wind tunnel, whicn simulated the airplane fuselage, and a significant amount of wing shielding was observed. The wings primarily shielded the fuselage from the pressure-surface noise of the propellers and indicated an up-inboard rotation would be needed for a low-wing airplane and a down-inboard rotation for a nigh-wing airplane. The up-inboard rotation is preferred for reducing installationcaused noise effects; so a low-wing airplane with up-inboard rotation combines both benefits.

As the axial Mach number was increased, the angle at whicn shielding started moved farther downstream. An explanation for this is that the diffracted wave around the leading edge of the wing is swept farther downstream, and therefore, the shielding starts farther downstream. An attempt to define the downstream movement of the start of the shielding with Mach number resulted in approximately a linear relationship with Mach number from $M=0.7$ up to $M=0.8$. At $M=0.85$ the start of the shielding does not shift any fartner downstream.

A simple no-flow barrier noise-reduction model was compared with the measured wing shieldiny, and showed similar trends with transducer position. The comparison indicated that the barrier method, if corrected for Macn number shift, might be used to roughly estimate the wing shielding. The $50^{\circ}, 55^{\circ}$-forward, and $60^{\circ}$ wing a 11 passed through the same point directly benind the propeller tip and exhibited similar shielding characteristics as predicted by the barrier model. The $55^{\circ}$-aft wing was located downstream of the other wings and, as predicted by the barrier model, showed a downstream shift in the axial location where shielding started.

The nigh wing sweeps tested here would probably not be present on an actual airplane, but shielding of the pressure-surface noise would still occur with lower swept wings. The area where shielding occurs would be shifted in angle with respect to those for the higher sweep wing. Tnis snift is indicated by the barrier model.

The wing, besides providing a barrier to the noise reaching the shielded side, also reflects some of the noise back onto the unshielded side. Tnis results in local regions where the reflected wave reinforces the direct wave and areas where it cancels. Where the reinforcement occurs the noise difference between the unshieided and shielded sides of the wing can be greater than the no-wing minus wing differences on the shielded side.

\section{Appendix}

Application of Barrier Method to Swept Wing snielding of Propeller Noise

In order to use the barrier method of Ref. 9 for the geometry of the wing and propeller experiment, a number of assumptions were necessary. The first assumption was that the pressure wave was, on average, coming off tangent to the circle of rotation of the propeller and that, again on average, it was emanating from the 3/4-radius point. The geometry is shown in Fig. 18(a), whicn is in the plane of rotation as seen from upstream looking downstream. Here $M$ is the 3/4-radius point of the propeller, $L$ is the distance the propeller centerline is located from the ceiling, and $Y$ is the distance the transducer is located from the ceiling centerline; all are known quantities. The line WT is the projection of the direct noise path d of Fig. 11 in this-plane.

From similar triangles

$$
\begin{aligned}
& \frac{W}{M}=\frac{U}{Y} \\
& \frac{S}{M}=\frac{T}{Y}
\end{aligned}
$$

Also

$$
\text { i) } \quad U+S=L
$$

From the upper triangle

$$
T^{2}=U^{2}+Y^{2}
$$

Substituting $T$ from $E q .(A 2)$ and then $S$ from Eq. (A3), a quadratic in $U$ can be determined.

$$
U^{2}\left(1-\frac{Y^{2}}{M^{2}}\right)+2 U L \frac{Y^{2}}{M^{2}}+Y^{2}\left(1-\frac{L^{2}}{M^{2}}\right)=0
$$

This can be soived for $U$ and subsequently $S$, $W$, and $T$ are determined.

The direct path $d$ to the transducer is the hypotenuse of the right triangle formed by the path WT and the distance the transducer is located axially from the plane of rotation $Z$. (See Fig. 5.) Therefore

$$
d=\sqrt{(W+T)^{2}+z^{2}}
$$

The effective neight of the barrier is assumed to be the distance that the leading edge of the wing is located from the propeller plane at the distance from the ceiling where the direct wave would intersect the wing. This is illustrated in Fig. 18(b). Here $C$ is the distance the leading eage of the wing is located where it touches the 
ceiling, $\theta$ is $90^{\circ}$ minus the wing-sweep angle, and $U$ is the distance from the ceiling; all are known quantities. The height of the barrier $\mathrm{J}$ is determined from

$$
\begin{aligned}
& P=\frac{U}{\tan \theta} \\
& J=C-P
\end{aligned}
$$

This then enables the calculation of $A$ and $B$, the path length over the barrier, from Fig. $18(\mathrm{C})$.

$$
\begin{gathered}
A=\sqrt{J^{2}+W^{2}} \\
B=\sqrt{T^{2}+(J+Z)^{2}}
\end{gathered}
$$

From here the Fresnel number $N$ can be calculated and the attenuation determined by using the for-. mula in the text.

\section{References}

1. Dittmar, James H.; Jeracki, Robert J.; and Blaha, Bernard J.: Tone Noise of Three Supersonic Helical Tip Speed Propellers in a Wind Tunnel. NASA TM-79167, 1979.

2. Dittmar, James H.; and Lasagna, Paul L.: A Preliminary Comparison Between the SR-3 Propeller Noise in Flight and in a Wind Tunnel. NASA TM-82805, 1982.

3. Mackall, K.G., et al.: In-Flight Acoustic Results from an Advanced-Design Propeller at
Mach Numbers to 0.8 . AIAA Paper 82-1120, June 1982 .

4. Lasagna, P.L.; Mackall, K.G.; and Cohn, R.B.: In-Flight Acoustic Test Results for the SR-2 and SR-3 Advanced-Design Propellers. AlAA Paper 83-1214, June 1983.

5. Dittmar, James H.: Feasibility of Wing Shielding of the Airplane Interior From the Shock Noise Generated by Supersonic Tip Speed Propellers. NASA TM-79042, 1978.

6. Metzger, F.B.: Progress and Trends in Propeller/Prop-Fan Noise Technology. AIAA Paper 80-0856, May 1980.

7. Jeracki, Robert J.; Mikkelson, Daniel C.; and Blaha, Bernard J.: Wind Tunnel Performance of Four Energy Efficient Propellers Designed for Mach 0.8 Cruise. SAE Paper 790573, Apr. 1979.

8. Brooks, B.M.; and Metzger, F.B.: Acoustic Test and Analys is of Three Advanced Turboprop Models. NASA CR-159667, 1980.

9. Dittmar, James H.: Why Credible Noise Measurements are Possible in The Acoustically Untreated NASA Lewis 8 Foot by 6 Foot Wind Tunnel. J. Acoust. Soc. Am., vol. 75 , no. 6 , June 1984, pp. 1913-1914.

10. Beranek, Leo L., ed.: Noise and Vibration Control. McGraw-Hi11, 1971, pp. 174-177. 
Table 1. - Comparison of Propellers

\begin{tabular}{|l|r|r|}
\hline \multicolumn{2}{|c|}{} & \\
& & \\
& & \\
\end{tabular}

Table 2. - Transducer Locations

\begin{tabular}{|c|c|c|c|c|c|}
\hline \multirow[t]{3}{*}{ Transducer } & \multicolumn{4}{|c|}{ Transducer positions } & \multirow{3}{*}{$\begin{array}{l}\text { Angle from } \\
\text { propeller axis, } \theta \\
\text { (includes } Z \text { and } Y \text { ) }\end{array}$} \\
\hline & \multicolumn{2}{|c|}{ Z } & \multicolumn{2}{|c|}{$\gamma$} & \\
\hline & $\mathrm{cm}$ & in & $\mathrm{cm}$ & in & \\
\hline $\begin{array}{l}1 N \\
1 S \\
2 N \\
2 S \\
3 N \\
3 S \\
4 N \\
4 S \\
5 N \\
5 S \\
6 N \\
6 S \\
7 N \\
7 S \\
8 N \\
8 S \\
9 N \\
9 S \\
10 N \\
10 S \\
11 N \\
11 S \\
12 N \\
12 S \\
13 N \\
13 S \\
14 N \\
14 S \\
15 N \\
15 S \\
16 N \\
16 S\end{array}$ & $\begin{array}{l}-94.3 \\
-94.3 \\
-76.52 \\
-76.52 \\
-58.74 \\
-58.74 \\
-23.18 \\
-23.18 \\
-5.4 \\
-5.4 \\
12.38 \\
12.38 \\
30.16 \\
30.16 \\
47.94 \\
47.94 \\
-91.6 \\
-91.6 \\
-73.82 \\
-73.82 \\
-56.04 \\
-56.04 \\
-20.48 \\
-20.48 \\
-2.7 \\
-2.7 \\
15.08 \\
15.08 \\
32.86 \\
32.86 \\
50.64 \\
50.64\end{array}$ & $\begin{array}{r}-37.125 \\
-37.125 \\
-30.125 \\
-30.125 \\
-23.125 \\
-23.125 \\
-9.125 \\
-9.125 \\
-2.125 \\
-2.125 \\
4.875 \\
4.875 \\
11.875 \\
11.875 \\
18.875 \\
18.875 \\
-36.0625 \\
-36.0625 \\
-29.0625 \\
-29.0625 \\
-22.0625 \\
-22.0625 \\
-8.0625 \\
-8.0625 \\
-1.0625 \\
-1.0625 \\
5.9375 \\
5.9375 \\
12.9375 \\
12.9375 \\
19.9375 \\
19.9375\end{array}$ & $\begin{array}{r}21.44 \\
-21.44 \\
.21 .44 \\
-21.44 \\
21.44 \\
-21.44 \\
21.44 \\
-21.44 \\
21.44 \\
-21.44 \\
21.44 \\
-21.44 \\
21.44 \\
-21.44 \\
21.44 \\
-21.44 \\
31.6 \\
-31.6 \\
31.6 \\
-31.6 \\
31.6 \\
-31.6 \\
31.6 \\
-31.6 \\
31.6 \\
-31.6 \\
31.6 \\
-31.6 \\
31.6 \\
-31.6 \\
31.6 \\
-31.6\end{array}$ & $\begin{array}{r}8.44 \\
-8.44 \\
8.44 \\
-8.44 \\
8.44 \\
-8.44 \\
8.44 \\
-8.44 \\
8.44 \\
-8.44 \\
8.44 \\
-8.44 \\
8.44 \\
-8.44 \\
8.44 \\
-8.44 \\
12.44 \\
-12.44 \\
12.44 \\
-12.44 \\
12.44 \\
-12.44 \\
12.44 \\
-12.44 \\
12.44 \\
-12.44 \\
12.44 \\
-12.44 \\
12.44 \\
-12.44 \\
12.44 \\
-12.44\end{array}$ & $\begin{array}{r}52.7 \\
52.7 \\
58.2 \\
58.2 \\
64.6 \\
64.6 \\
79.4 \\
79.4 \\
87.5 \\
87.5 \\
95.7 \\
99.7 \\
103.7 \\
103.7 \\
111.2 \\
111.2 \\
53.9 \\
53.9 \\
59.6 \\
59.6 \\
66.0 \\
66.0 \\
80.8 \\
80.8 \\
88.8 \\
88.8 \\
96.8 \\
96.8 \\
104.6 \\
104.6 \\
111.9 \\
111.9\end{array}$ \\
\hline
\end{tabular}


Taole 3. - SR-2 Blade Passage Tone Data

(a) No-wing

\begin{tabular}{|c|c|c|c|c|c|c|c|c|c|c|c|c|c|c|c|c|}
\hline \multirow{3}{*}{$\begin{array}{c}\text { Macn } \\
\text { number }\end{array}$} & \multicolumn{16}{|c|}{ Transducer } \\
\hline & \multicolumn{8}{|c|}{ North wall } & \multicolumn{8}{|c|}{ Soutn wall } \\
\hline & 1 & 2 & 3 & 4 & 5 & 6 & 7 & 8 & 1 & 2 & 3 & 4 & 5 & 6 & 7 & $8:$ \\
\hline $\begin{array}{l}0.6 \\
.7 \\
.75 \\
.8 \\
.85\end{array}$ & $\begin{array}{c}138.0 \\
155.0 \\
150.1 \\
139.4 \\
\text { (a) }\end{array}$ & $\begin{array}{c}139.5 \\
155.1 \\
149.2 \\
138.2 \\
\text { (a) }\end{array}$ & $\begin{array}{c}142.6 \\
156.4 \\
147.4 \\
142.1 \\
\text { (a) }\end{array}$ & $\begin{array}{c}146.3 \\
149.2 \\
159.1 \\
149.8 \\
\text { (a) }\end{array}$ & $\begin{array}{l}147.4 \\
156.2 \\
162.0 \\
153.3 \\
144.2\end{array}$ & $\begin{array}{l}147.1 \\
153.4 \\
162.0 \\
158.0 \\
150.3\end{array}$ & $\begin{array}{l}146.4 \\
152.6 \\
164.8 \\
154.0 \\
155.2\end{array}$ & $\begin{array}{l}141.4 \\
152.3 \\
159.4 \\
152.6 \\
156.8\end{array}$ & $\begin{array}{c}139.4 \\
148.5 \\
150.1 \\
139.8 \\
\text { (a) }\end{array}$ & $\begin{array}{c}137.1 \\
155.0 \\
150.3 \\
142.1 \\
\text { (a) }\end{array}$ & $\begin{array}{c}138.6 \\
157.3 \\
148.5 \\
145.1 \\
\text { (a) }\end{array}$ & $\begin{array}{c}144.7 \\
149.8 \\
158.2 \\
150.0 \\
\text { (a) }\end{array}$ & $\begin{array}{l}144.4 \\
155.1 \\
160.3 \\
149.2 \\
147.2\end{array}$ & $\begin{array}{l}144.4 \\
156.0 \\
163.8 \\
158.5 \\
151.4\end{array}$ & $\begin{array}{l}141.5 \\
155.0 \\
156.0 \\
156.0 \\
157.7\end{array}$ & $\begin{array}{l}133.9 \\
150.4 \\
162.3 \\
152.3 \\
158.5\end{array}$ \\
\hline
\end{tabular}

(b) $60^{\circ}$ wing

\begin{tabular}{|c|c|c|c|c|c|c|c|c|c|c|c|c|c|c|c|c|}
\hline $\begin{array}{l}0.6 \\
.7 \\
.75 \\
.8 \\
.85\end{array}$ & $\begin{array}{c}149.1 \\
146.9 \\
137.8 \\
(\mathrm{a})\end{array}$ & $\begin{array}{c}127.8 \\
149.3 \\
148.0 \\
139.4 \\
(\mathrm{a})\end{array}$ & $\begin{array}{c}(\mathrm{b}) \\
146.2 \\
150.7 \\
(\mathrm{~b}) \\
(\mathrm{b})\end{array}$ & $\begin{array}{c}147.9 \\
151.8 \\
148.8 \\
\text { (a) }\end{array}$ & $\begin{array}{l}141.2 \\
148.7 \\
149.9 \\
146.7 \\
141.3\end{array}$ & $\begin{array}{l}139.8 \\
146.4 \\
153.4 \\
149.5 \\
144.8\end{array}$ & $\begin{array}{l}132.7 \\
149.4 \\
149.1 \\
147.2 \\
151.5\end{array}$ & $\begin{array}{l}127 \\
145 \\
151 \\
157 \\
154\end{array}$ & $\begin{array}{c}130.6 \\
144.6 \\
143.2 \\
138.3 \\
\text { (a) }\end{array}$ & $\begin{array}{c}135.3 \\
151.1 \\
145.8 \\
141.7 \\
(\mathrm{a})\end{array}$ & $\begin{array}{l}1 \\
165 \\
14 \\
135 \\
1\end{array}$ & & & & & \\
\hline
\end{tabular}

${ }^{a}$ Tone below tunnel background.

Dad transducer, data channél, etc.

(c) $55^{\circ}$-forward wing

\begin{tabular}{|c|c|c|c|c|c|c|c|c|c|c|c|c|c|c|c|c|}
\hline \multirow{3}{*}{$\begin{array}{c}\text { Mach } \\
\text { number }\end{array}$} & \multicolumn{16}{|c|}{ Transducer } \\
\hline & \multicolumn{8}{|c|}{ North wall } & \multicolumn{8}{|c|}{ South wall } \\
\hline & 1 & 2 & 3 & 4 & 5 & 6 & 7 & 8 & 1 & 2 & 3 & 4 & 5 & 6 & 7 & 8 \\
\hline $\begin{array}{l}0.6 \\
.7 \\
.75 \\
.8 \\
.85\end{array}$ & $\begin{array}{c}129.0 \\
155.1 \\
145.6 \\
139.8 \\
\text { (a) }\end{array}$ & $\begin{array}{c}131.8 \\
150.8 \\
147.8 \\
141.8 \\
(\mathrm{a})\end{array}$ & $\begin{array}{c}134.9 \\
149.6 \\
151.2 \\
140.1 \\
\text { (a) }\end{array}$ & $\begin{array}{c}138.9 \\
147.0 \\
153.9 \\
152.6 \\
\text { (a) }\end{array}$ & $\begin{array}{l}141.8 \\
146.6 \\
149.7 \\
152.7 \\
142.0\end{array}$ & $\begin{array}{l}141.9 \\
146.3 \\
148.6 \\
147.3 \\
145.4\end{array}$ & $\begin{array}{l}139.0 \\
149.0 \\
149.2 \\
151.0 \\
152.1\end{array}$ & $\begin{array}{l}131.0 \\
148.4 \\
151.0 \\
151.7 \\
148.9\end{array}$ & $\begin{array}{c}135.6 \\
147.4 \\
144.9 \\
139.1 \\
\text { (a) }\end{array}$ & $\begin{array}{c}135.9 \\
153.4 \\
148.5 \\
139.2 \\
\text { (a) }\end{array}$ & $\begin{array}{c}133.0 \\
160.6 \\
147.7 \\
141.5 \\
\text { (a) }\end{array}$ & $\begin{array}{c}144.4 \\
149.9 \\
159.4 \\
152.7 \\
(a)\end{array}$ & $\begin{array}{l}145.9 \\
157.6 \\
161.8 \\
154.5 \\
148.8\end{array}$ & $\begin{array}{l}142.6 \\
157.7 \\
157.7 \\
155.8 \\
155.6\end{array}$ & $\begin{array}{l}138.7 \\
153.2 \\
161.0 \\
158.3 \\
159.4\end{array}$ & $\begin{array}{l}130.9 \\
147.4 \\
162.0 \\
157.6 \\
158.1\end{array}$ \\
\hline
\end{tabular}

(d) $50^{\circ}$ wing

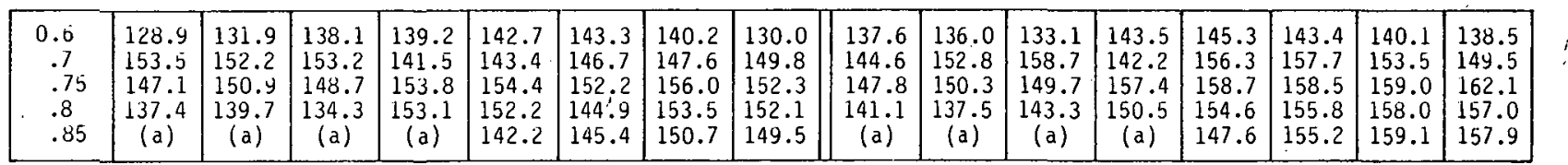

${ }^{2}$ Tone be low tunnel background.

(e) $55^{\circ}$ aft wing

\begin{tabular}{|c|c|c|c|c|c|c|c|c|c|c|c|c|c|c|c|c|}
\hline \multirow{3}{*}{$\begin{array}{l}\text { Macn } \\
\text { number }\end{array}$} & \multicolumn{16}{|c|}{ Transducer } \\
\hline & \multicolumn{8}{|c|}{ North wall } & \multicolumn{8}{|c|}{ South wall } \\
\hline & 1 & 2 & 3 & 4 & 5 & 6 & 7 & 8 & 1 & 2 & 3 & 4 & 5 & 6 & 7 & 8 \\
\hline $\begin{array}{l}0.6 \\
.7 \\
.75 \\
.8 \\
.85\end{array}$ & $\begin{array}{c}135.7 \\
155.3 \\
145.5 \\
137.9 \\
\text { (a) }\end{array}$ & $\begin{array}{c}137.0 \\
154.6 \\
148.4 \\
138.5 \\
\text { (a) }\end{array}$ & $\begin{array}{c}141.7 \\
154.6 \\
152.2 \\
142.3 \\
\text { (a) }\end{array}$ & $\begin{array}{l}143.9 \\
147.2 \\
155.4 \\
150.3 \\
\text { (d) }\end{array}$ & $\begin{array}{l}144.3 \\
149.3 \\
158.2 \\
146.3 \\
143.3\end{array}$ & $\begin{array}{l}146.4 \\
143.4 \\
153.4 \\
149.4 \\
145.2\end{array}$ & $\begin{array}{l}146.1 \\
151.4 \\
153.4 \\
143.3 \\
154.5\end{array}$ & $\begin{array}{l}141.6 \\
150.5 \\
148.8 \\
152.0 \\
153.7\end{array}$ & $\begin{array}{c}137.0 \\
146.2 \\
147.4 \\
136.2 \\
\text { (a) }\end{array}$ & $\begin{array}{c}139.6 \\
154.1 \\
151.3 \\
140.7 \\
(\mathrm{a})\end{array}$ & $\begin{array}{c}142.0 \\
159.1 \\
151.9 \\
142.7 \\
\text { (a) }\end{array}$ & $\begin{array}{c}145.9 \\
144.4 \\
155.5 \\
151.9 \\
\text { (a) }\end{array}$ & $\begin{array}{l}145.8 \\
156.1 \\
159.4 \\
153.6 \\
146.3\end{array}$ & $\begin{array}{l}146.0 \\
159.1 \\
157.2 \\
153.1 \\
154.1\end{array}$ & $\begin{array}{l}145.3 \\
154.7 \\
158.2 \\
155.8 \\
158.6\end{array}$ & $\begin{array}{l}140.9 \\
145.0 \\
162.5 \\
157.4 \\
158.7\end{array}$ \\
\hline
\end{tabular}

aTone below tunnel background. 
Taole 4. - SR-3 Blade Passage Tone Data

(a) No-wing

\begin{tabular}{|c|c|c|c|c|c|c|c|c|c|c|c|c|c|c|c|c|}
\hline \multirow{3}{*}{$\begin{array}{c}\text { Macn } \\
\text { number }\end{array}$} & \multicolumn{16}{|c|}{ Transducer } \\
\hline & \multicolumn{8}{|c|}{ North wall } & \multicolumn{8}{|c|}{ South wall } \\
\hline & 1 & 2 & 3 & 4 & 5 & 6 & 7 & 8 & 1 & 2 & 3 & 4 & 5 & 6 & 7 & 8 \\
\hline $\begin{array}{l}0.6 \\
.7 \\
.75 \\
.8 \\
.85\end{array}$ & $\begin{array}{c}131.9 \\
145.4 \\
143.7 \\
133.8 \\
\text { (a) }\end{array}$ & $\begin{array}{c}136.7 \\
145.9 \\
142.8 \\
134.9 \\
\text { (a) }\end{array}$ & $\begin{array}{c}140.0 \\
146.0 \\
143.3 \\
139.5 \\
\text { (a) }\end{array}$ & $\begin{array}{c}142.1 \\
(b) \\
147.1 \\
143.4 \\
(a)\end{array}$ & $\begin{array}{l}143.6 \\
148.9 \\
149.3 \\
140.9 \\
143.3\end{array}$ & $\begin{array}{l}144.9 \\
150.1 \\
155.7 \\
151.2 \\
147.1\end{array}$ & $\begin{array}{c}143.1 \\
(\mathrm{~b}) \\
154.9 \\
151.1 \\
147.2\end{array}$ & $\begin{array}{l}141.7 \\
147.9 \\
155.9 \\
153.3 \\
155.2\end{array}$ & $\begin{array}{c}134.1 \\
138.7 \\
139.9 \\
137.3 \\
(\mathrm{a})\end{array}$ & $\begin{array}{c}135.9 \\
142.2 \\
141.4 \\
140.4 \\
\text { (a) }\end{array}$ & $\begin{array}{c}136.4 \\
144.6 \\
141.7 \\
140.5 \\
\text { (a) }\end{array}$ & $\begin{array}{l}\text { (b) } \\
\text { (b) } \\
\text { (b) } \\
\text { (b) } \\
\text { (c) }\end{array}$ & $\begin{array}{c}140.8 \\
143.5 \\
152.1 \\
146.1 \\
\text { (a) }\end{array}$ & $\begin{array}{l}142.6 \\
149.0 \\
153.6 \\
148.4 \\
148.6\end{array}$ & $\begin{array}{l}140.6 \\
150.6 \\
150.7 \\
143.6 \\
149.4\end{array}$ & $\begin{array}{l}133.8 \\
148.0 \\
157.1 \\
151.8 \\
151.8\end{array}$ \\
\hline
\end{tabular}

(b) $60^{\circ}$ wing

\begin{tabular}{|c|c|c|c|c|c|c|c|c|c|c|c|c|c|c|c|c|}
\hline $\begin{array}{l}0.6 \\
.7 \\
.75 \\
.8 \\
.85\end{array}$ & $\begin{array}{c}(\mathrm{a}) \\
144.8 \\
144.8 \\
136.2 \\
(\mathrm{a})\end{array}$ & $\begin{array}{c}144.0 \\
144.0 \\
137.2 \\
(\mathrm{a})\end{array}$ & $\begin{array}{c}143.9 \\
138.7 \\
(\mathrm{a})\end{array}$ & $\begin{array}{c}144 .^{3} \\
(a)^{3}\end{array}$ & $\begin{array}{l}138.8 \\
141.2 \\
145.6 \\
140.6\end{array}$ & $\begin{array}{l}149.7 \\
140.3\end{array}$ & $\begin{array}{c}(b) \\
(b) \\
151.5 \\
(b) \\
142.2\end{array}$ & & $\begin{array}{c}136.8 \\
(a)\end{array}$ & $\begin{array}{c}140.0 \\
\text { (a) }\end{array}$ & $\begin{array}{r}138 \\
1 \mathrm{a}\end{array}$ & $\begin{array}{l}\text { (b) } \\
\text { (b) } \\
\text { (b) } \\
\text { (b) } \\
\text { (b) }\end{array}$ & & $\begin{array}{l}154.5 \\
148.9\end{array}$ & $\begin{array}{l}140.9 \\
152.3 \\
151.5 \\
151.9 \\
154.4\end{array}$ & $\begin{array}{l}140.2 \\
146.8 \\
158.2 \\
156.7 \\
153.2\end{array}$ \\
\hline
\end{tabular}

aTone below tunnel dackground.

Dad transducer, data channel, etc.

(c) $55^{\circ}$ forward wing

\begin{tabular}{|c|c|c|c|c|c|c|c|c|c|c|c|c|c|c|c|c|}
\hline \multirow{3}{*}{$\begin{array}{c}\text { Mach } \\
\text { number }\end{array}$} & \multicolumn{16}{|c|}{ Transducer } \\
\hline & \multicolumn{8}{|c|}{ North wall } & \multicolumn{8}{|c|}{ South wall } \\
\hline & 1 & 2 & 3 & 4 & 5 & 6 & 7 & 8 & 1 & 2 & 3 & 4 & 5 & 6 & 7 & 8 \\
\hline $\begin{array}{l}0.6 \\
.7 \\
.75 \\
.8 \\
.85\end{array}$ & $\begin{array}{c}127.9 \\
146.0 \\
143.1 \\
135.7 \\
(a)\end{array}$ & $\begin{array}{l}(\mathrm{b}) \\
(\mathrm{b}) \\
(\mathrm{b}) \\
(\mathrm{b}) \\
(\mathrm{D})\end{array}$ & $\begin{array}{c}136.6 \\
140.0 \\
143.5 \\
141.6 \\
\text { (a) }\end{array}$ & $\begin{array}{c}136.9 \\
136.0 \\
143.1 \\
146.5 \\
(a)\end{array}$ & $\begin{array}{l}139.1 \\
139.6 \\
146.6 \\
144.9 \\
142.5\end{array}$ & $\begin{array}{l}140.0 \\
135.7 \\
148.6 \\
147.4 \\
144.1\end{array}$ & $\begin{array}{l}139.9 \\
144.5 \\
149.0 \\
147.7 \\
145.2\end{array}$ & $\begin{array}{l}140.8 \\
141.4 \\
147.4 \\
153.7 \\
149.2\end{array}$ & $\begin{array}{c}130.9 \\
134.4 \\
143.5 \\
138.6 \\
(a)\end{array}$ & $\begin{array}{c}132.5 \\
142.6 \\
145.1 \\
141.2 \\
(a)\end{array}$ & $\begin{array}{c}131.4 \\
148.8 \\
145.9 \\
136.3 \\
(a)\end{array}$ & $\begin{array}{l}\text { (b) } \\
\text { (b) } \\
\text { (b) } \\
\text { (b) } \\
\text { (b) }\end{array}$ & $\begin{array}{l}141.7 \\
151.1 \\
150.9 \\
152.8 \\
147.2\end{array}$ & $\begin{array}{l}140.3 \\
153.9 \\
152.7 \\
153.5 \\
150.5\end{array}$ & $\begin{array}{l}141.2 \\
151.8 \\
151.2 \\
151.0 \\
155.3\end{array}$ & $\begin{array}{l}139.1 \\
146.9 \\
157.6 \\
156.4 \\
153.4\end{array}$ \\
\hline
\end{tabular}

(d) $50^{\circ}$ wing

\begin{tabular}{|c|c|c|c|c|c|c|c|c|c|c|c|c|c|c|c|c|}
\hline & 2.3 & (D) & 9.5 & 37.0 & 138.1 & 141 & 139 & 13 & 1 & 131.4 & 13 & (b) & 139.3 & 140.9 & 141.3 & 141.1 \\
\hline & 1 & (b) & & & & & 143 & & & 3 & & & & 15 & & 14 \\
\hline .75 & 1 & (D) & 145.3 & 142.9 & 147.9 & 150 & 147 & 146 & 142 & 148.7 & 148 & (b & & 151.3 & 14 & 157.8 \\
\hline 8 & 13 & (b) & 142.1 & 147.5 & 1 & 14 & 14 & 15 & 136.1 & 140.9 & 136 & (b) & 15 & 153.1 & 150.9 & 156.6 \\
\hline 8 & (a) & (0) & (a) & (a) & 141.8 & 143.9 & 144.0 & 149.9 & (a) & (a) & (a) & (D) & 147.5 & 150.4 & 153.8 & 152.5 \\
\hline
\end{tabular}

aTone below tunnel background.

bad transducer, data channel, etc.

(e) $55^{\circ}$ aft wing

\begin{tabular}{|c|c|c|c|c|c|c|c|c|c|c|c|c|c|c|c|c|}
\hline \multirow{3}{*}{$\begin{array}{c}\text { Mach } \\
\text { number }\end{array}$} & \multicolumn{16}{|c|}{ Transducer } \\
\hline & \multicolumn{8}{|c|}{ North wall } & \multicolumn{8}{|c|}{ South wall } \\
\hline & 1 & 2 & 3 & 4 & 5 & 6 & 7 & 8 & 1 & 2 & 3 & 4 & 5 & 6 & 7 & 8 \\
\hline $\begin{array}{l}0.6 \\
.7 \\
.75 \\
.8 \\
.85\end{array}$ & $\begin{array}{c}132.5 \\
148.0 \\
142.0 \\
136.3 \\
\text { (a) }\end{array}$ & $\begin{array}{c}\text { (b) } \\
\text { (b) } \\
143.4 \\
137.2 \\
\text { (a) }\end{array}$ & $\begin{array}{c}141.1 \\
145.0 \\
144.2 \\
138.0 \\
\text { (a) }\end{array}$ & $\begin{array}{c}141.3 \\
138.6 \\
146.2 \\
147 . \overline{0} \\
(\mathrm{a})\end{array}$ & $\begin{array}{l}141.8 \\
145.9 \\
147.6 \\
144.4 \\
144.1\end{array}$ & $\begin{array}{l}143.7 \\
143.5 \\
147.5 \\
148.5 \\
143.2\end{array}$ & $\begin{array}{l}143.0 \\
138.0 \\
147.8 \\
144.1 \\
142.2\end{array}$ & $\begin{array}{l}145.3 \\
147.4 \\
148.7 \\
154.4 \\
151.7\end{array}$ & $\begin{array}{c}133.2 \\
136.8 \\
144.0 \\
134.6 \\
\text { (a) }\end{array}$ & $\begin{array}{c}133.3 \\
143.9 \\
144.4 \\
140.1 \\
(a)\end{array}$ & $\begin{array}{c}137.3 \\
148.2 \\
145.4 \\
137.0 \\
(\mathrm{a})\end{array}$ & $\begin{array}{l}\text { (b) } \\
\text { (b) } \\
\text { (b) } \\
(\mathrm{b}) \\
\text { (b) }\end{array}$ & $\begin{array}{l}139.9 \\
150.1 \\
149.2 \\
150.0 \\
145.1\end{array}$ & $\begin{array}{l}141.7 \\
153.7 \\
152.0 \\
149.2 \\
149.5\end{array}$ & $\begin{array}{l}143.5 \\
152.8 \\
154.2 \\
147.3 \\
150.7\end{array}$ & $\begin{array}{l}142.6 \\
148.4 \\
155.8 \\
155.3 \\
150.9\end{array}$ \\
\hline
\end{tabular}

aTone delow tunnel background.

DBad transducer, data channel, etc. 


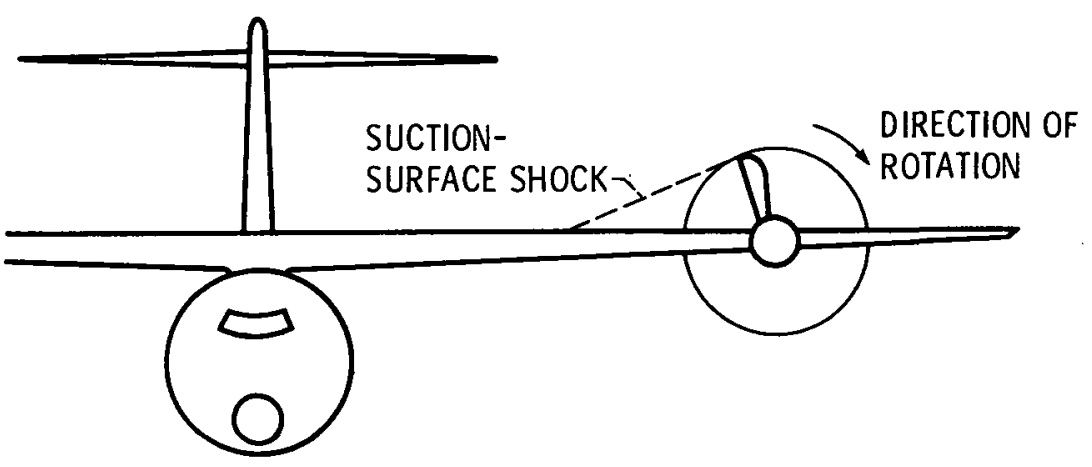

(a) Blocking of suction surface shock.

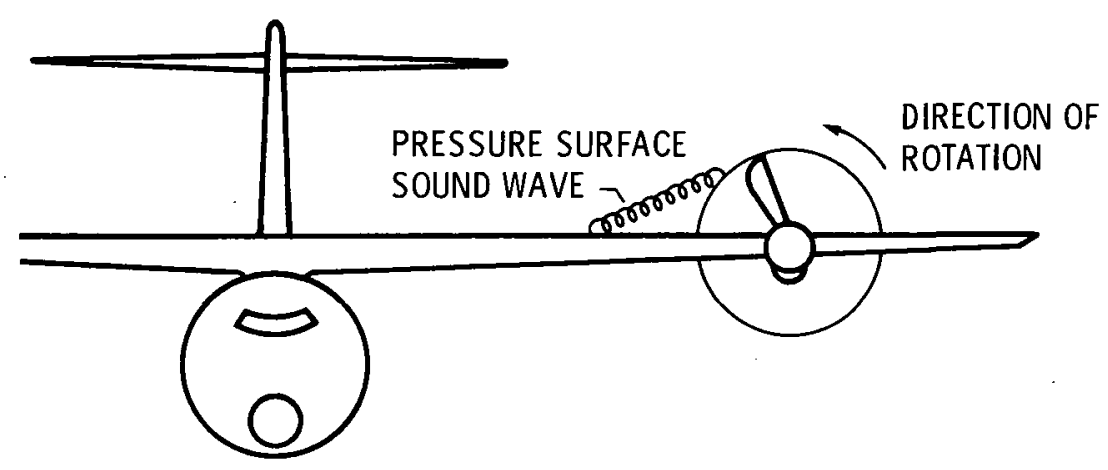

(b) Blocking of pressure surface sound.

Figure 1. - Wing shielding. 


\section{ORIGINAL PAGE IS}

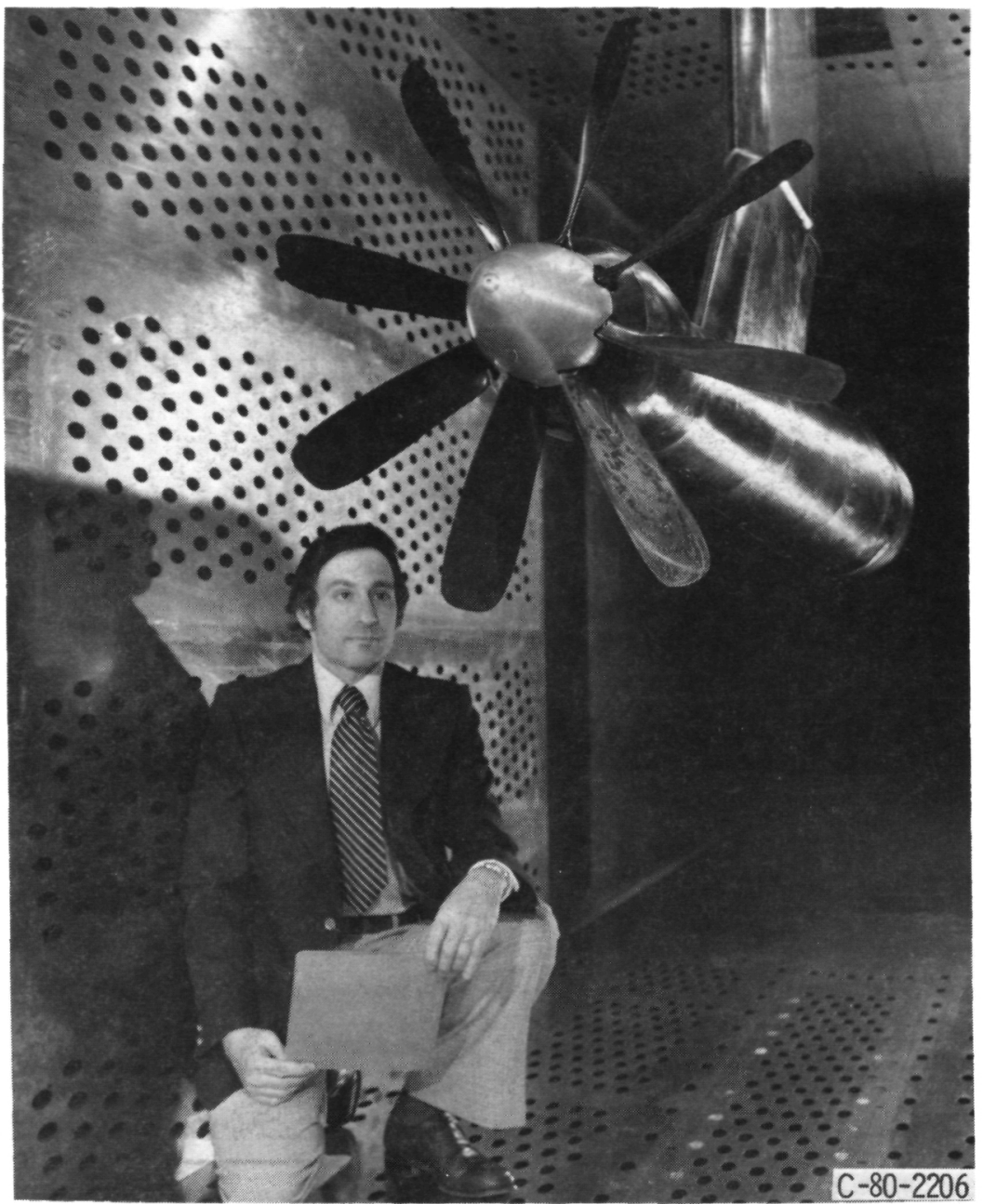

(a) SR-2 propeller in 8-by-6-Foot Wind Tunnel.

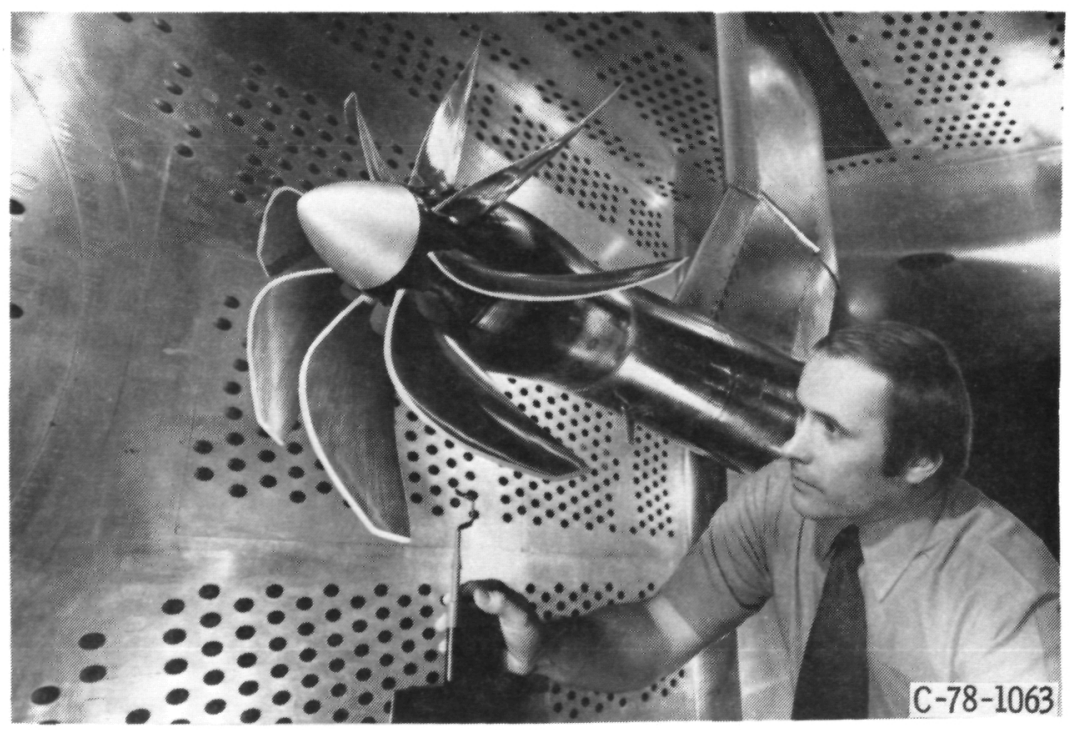

(b) SR-3 propeller in 8-by-6-Foot Wind Tunnel.

Figure 2。 


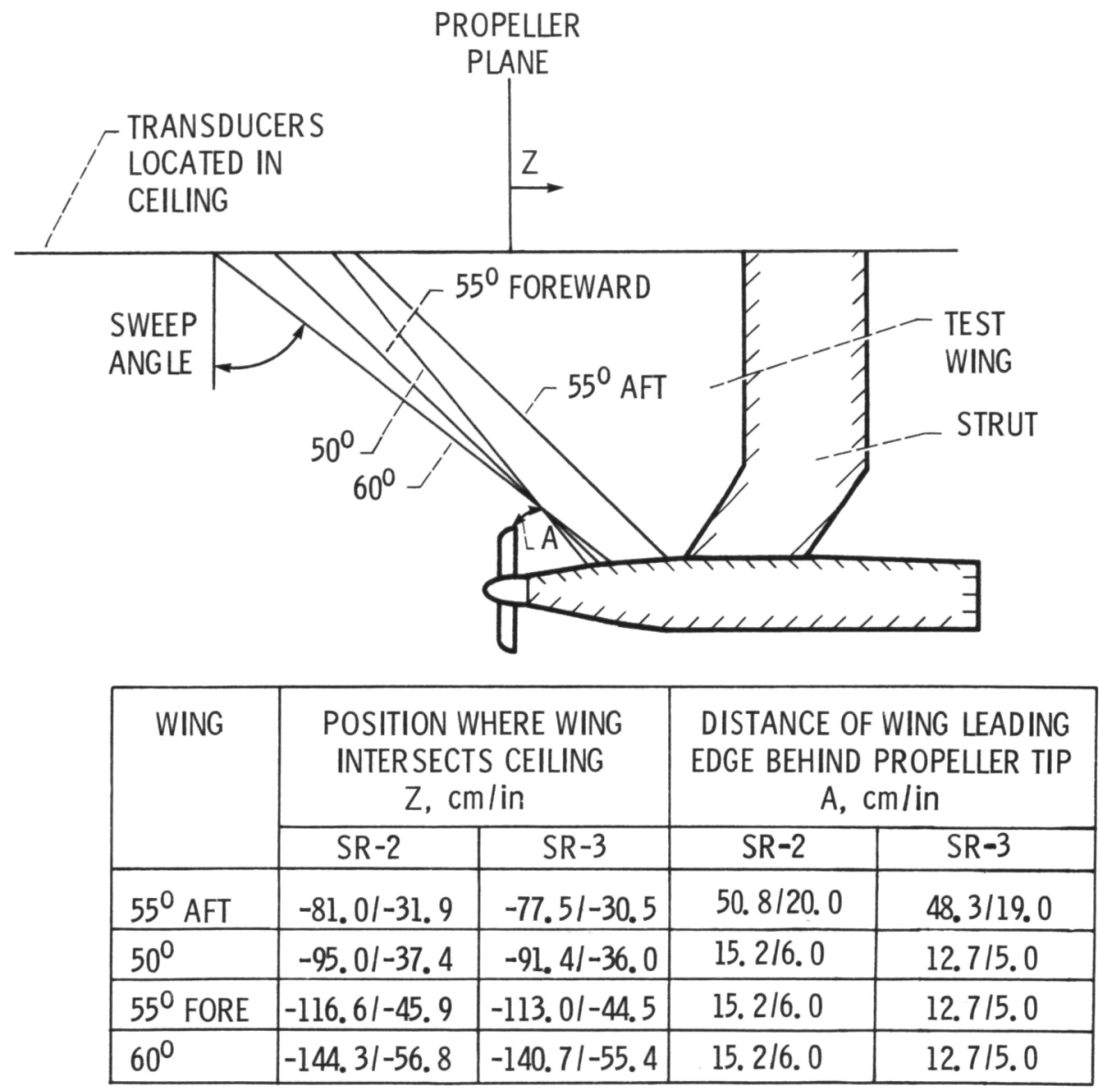

Figure 3. - Wing positions. 


\section{ORIGINAL PAGE IS \\ OF POOR QUALITY}

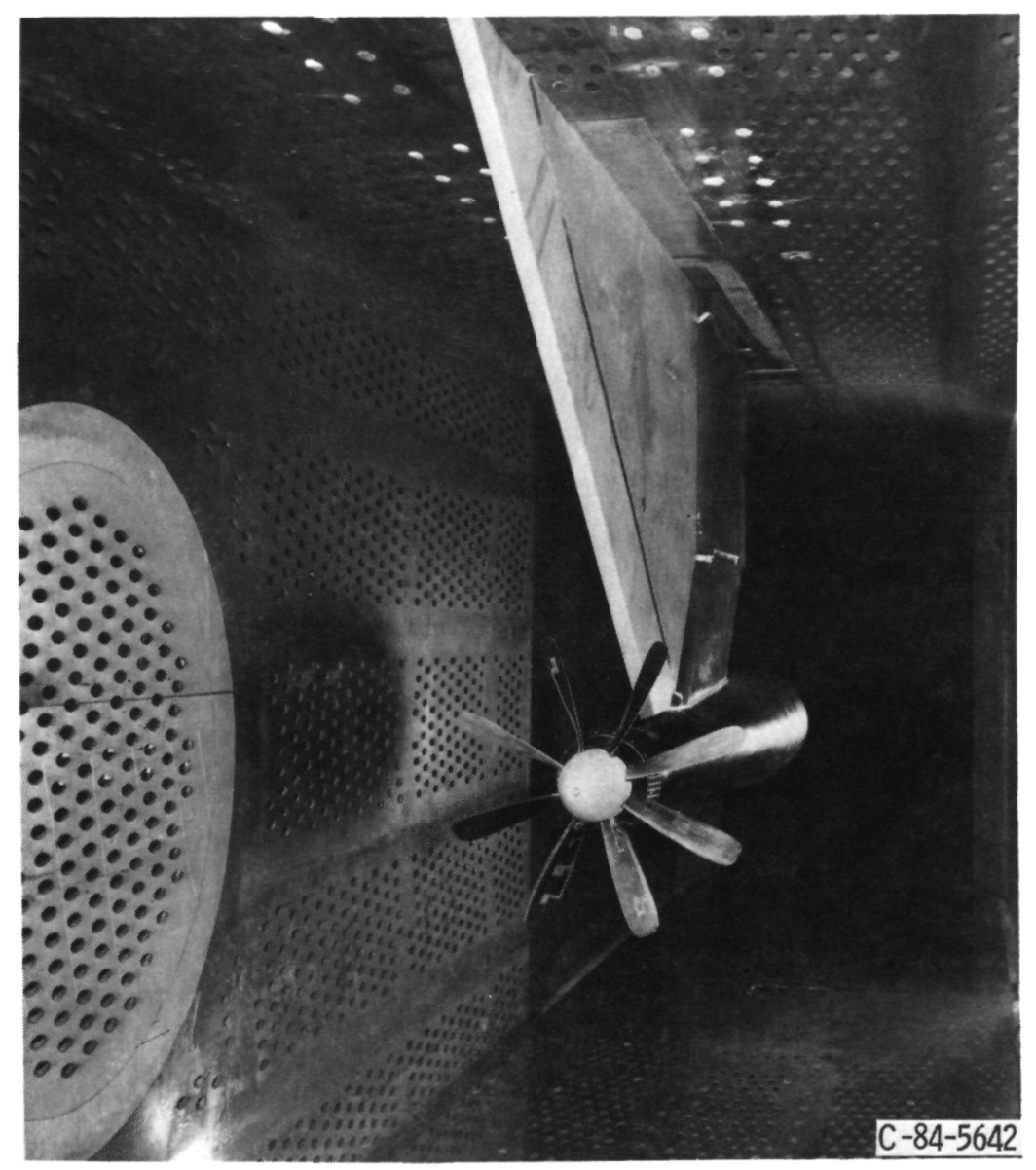

(a) SR-2 propeller.

Figure 4. - Propeller with $55^{\circ}$-forward wing in wind tunnel. 


\section{ORIGINAL PAGE IS \\ OF POOR QUALTTY}

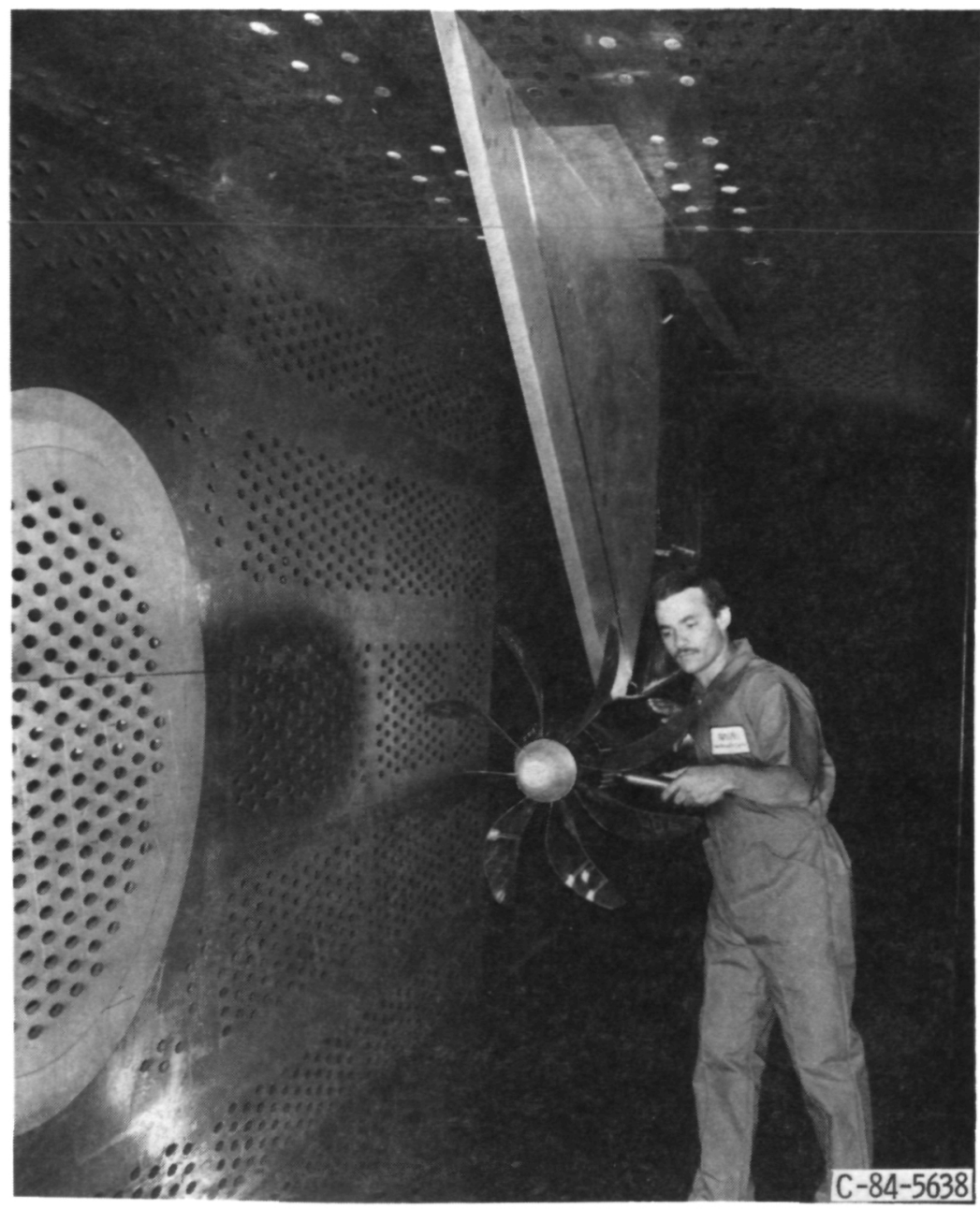

(b) SR-3 propeller.

Figure 4. - Concluded.

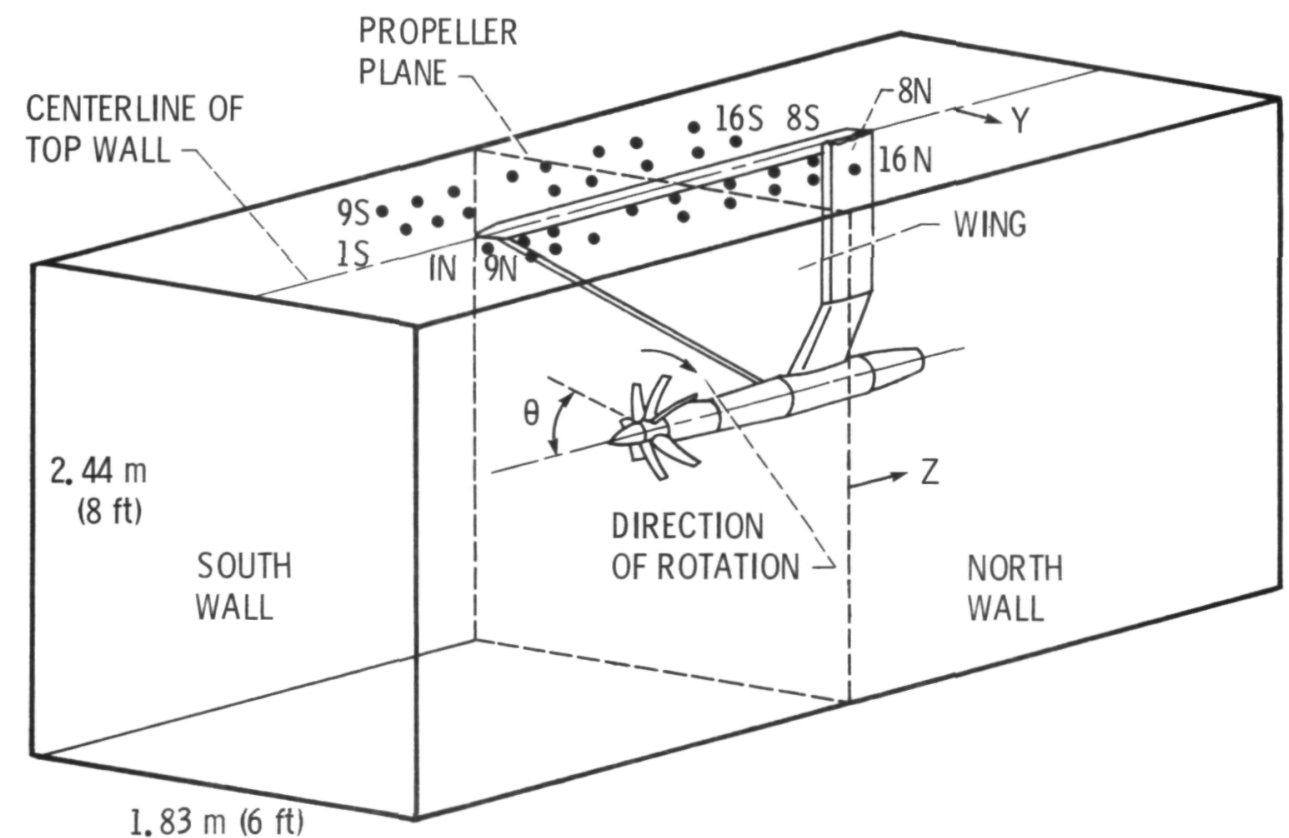

Figure 5. - Transducer positions. 


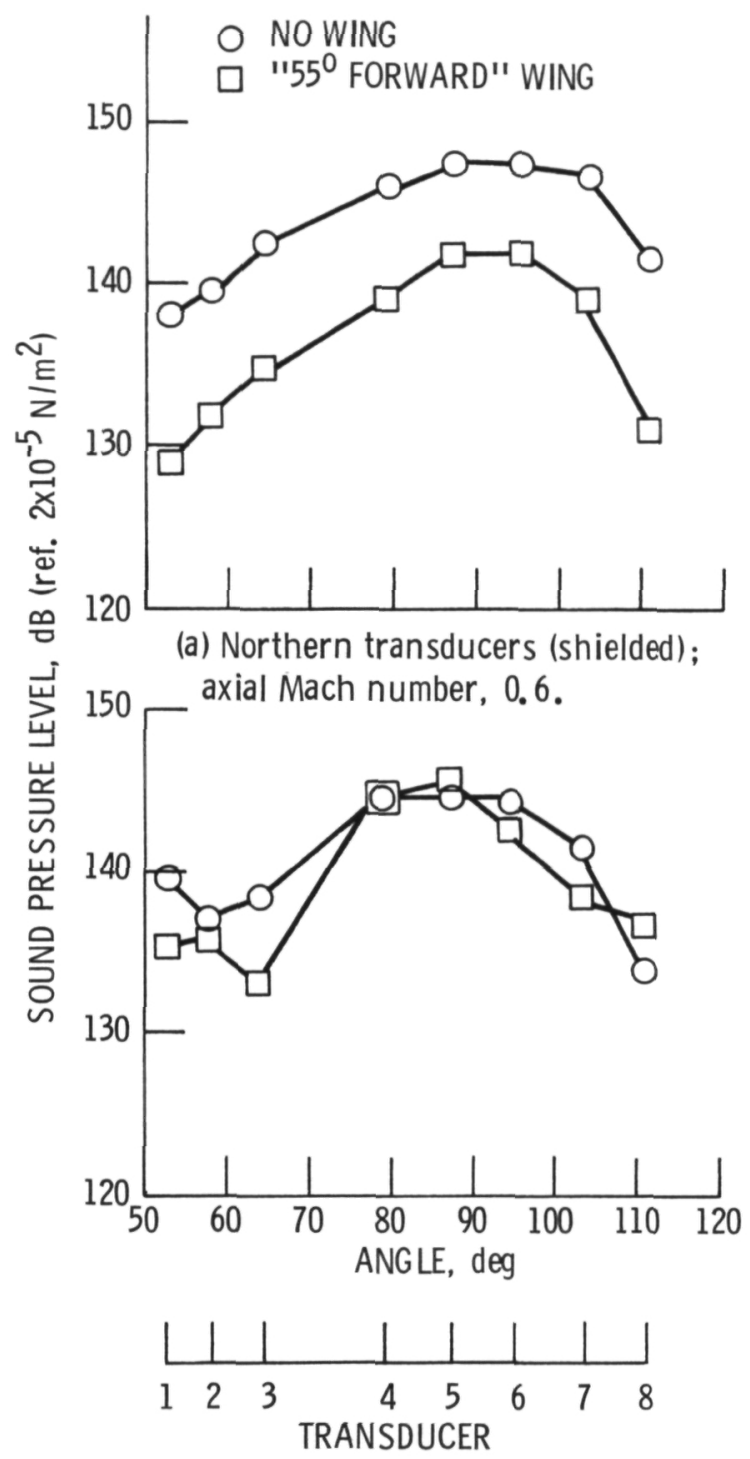

(b) Southern transducers (unshielded); axial Mach number, 0.6.

Figure 6. - Blade passing tone sound pressure level versus position for SR-2 propeller. 


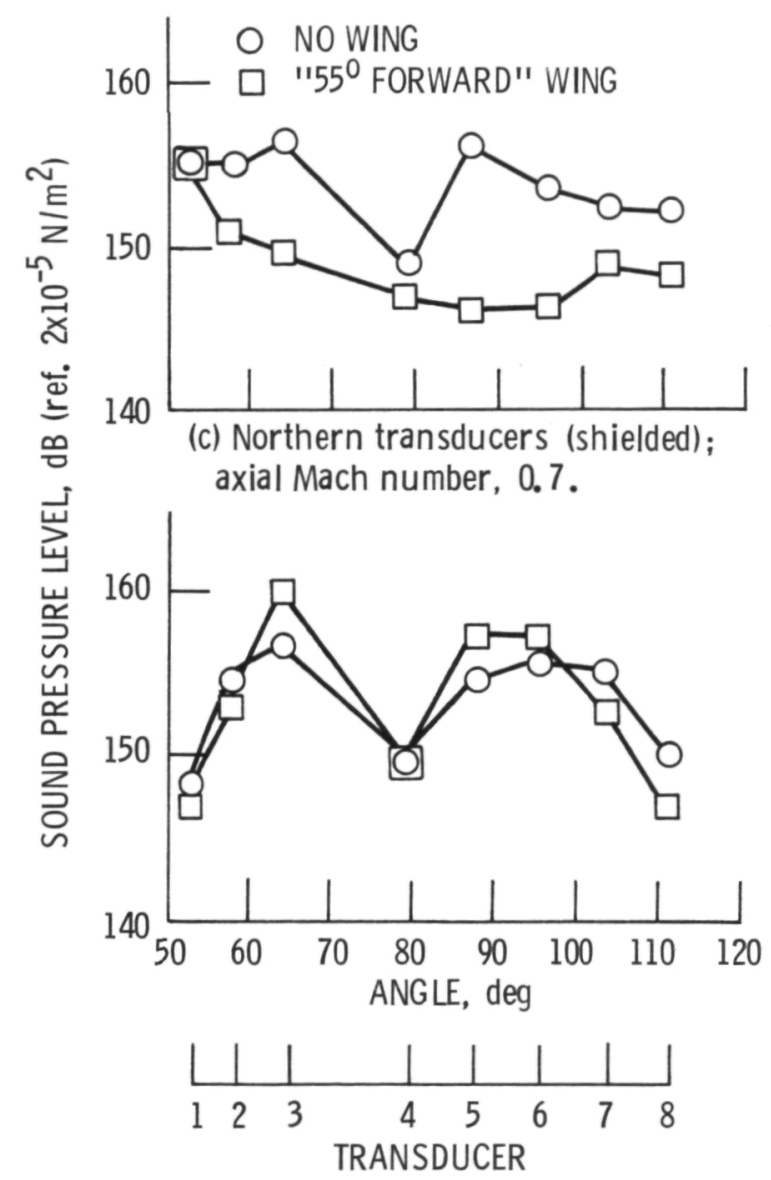

(d) Southern transducer (unshielded); axial Mach number, 0.7.

Figure 6. - Continued. 


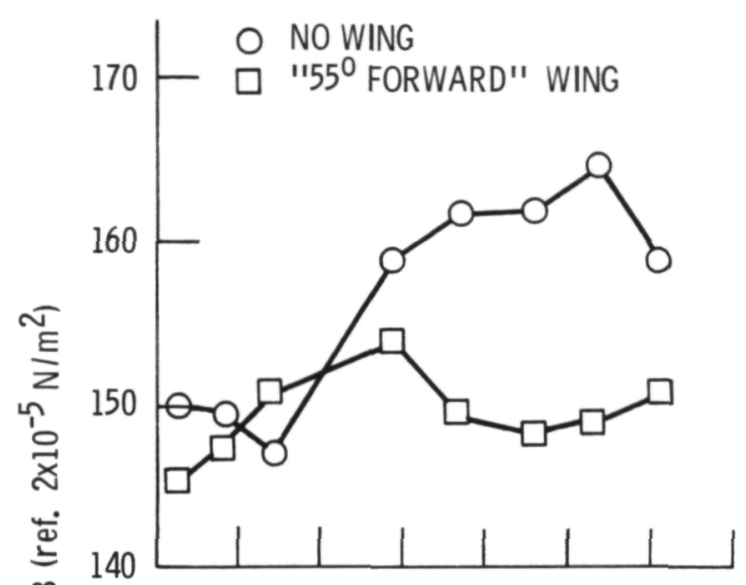

๑ (e) Northern transducers (shielded);

- 170 axial Mach number 0.75 .
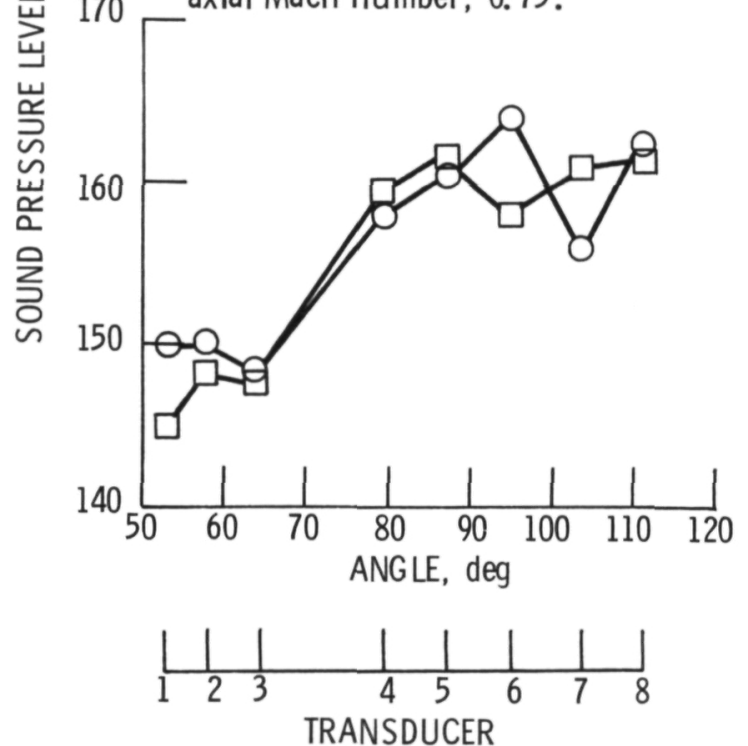

(f) Southern transducers (unshielded); axial Mach number, 0.75 .

Figure 6. - Continued. 


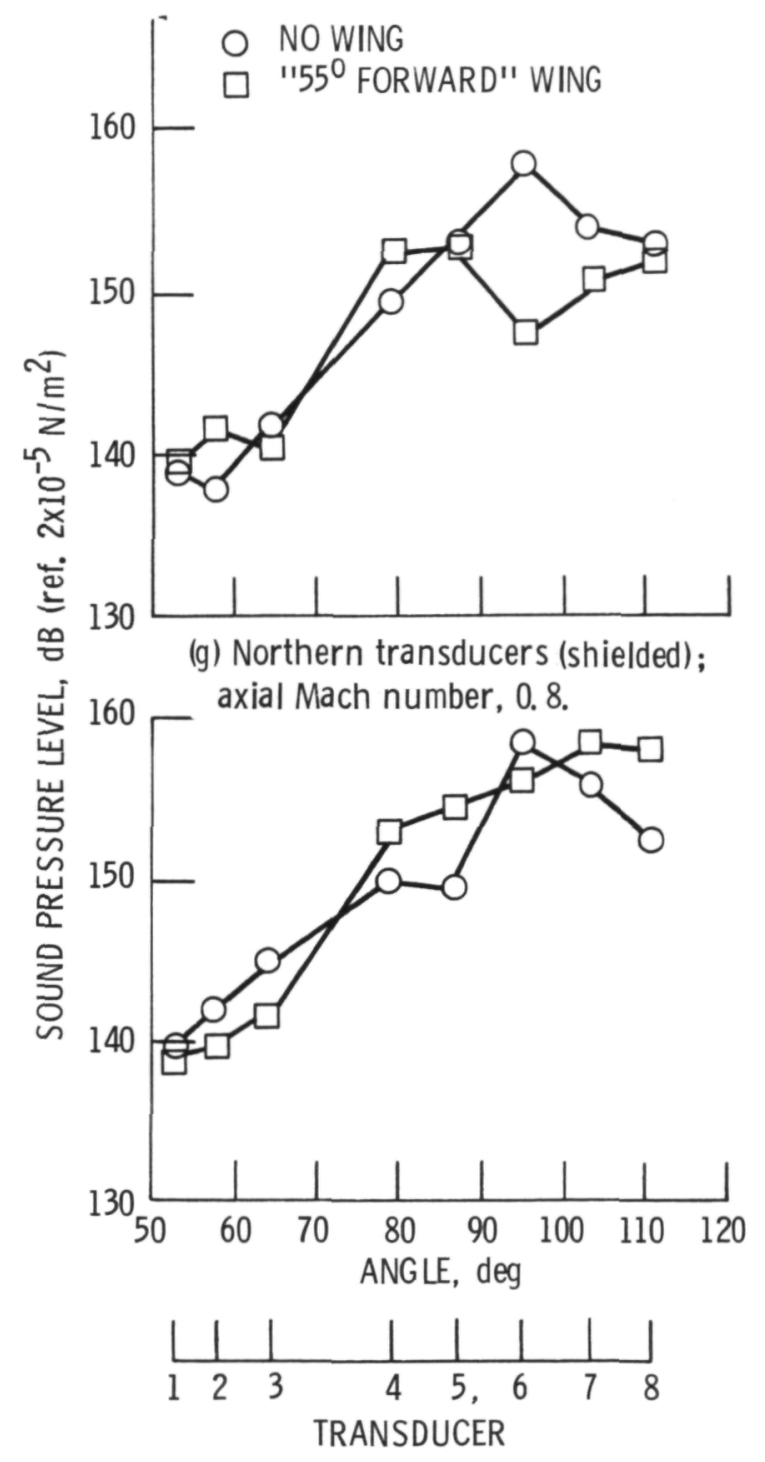

(h) Southern transducers (unshielded); axial Mach number, 0.8.

Figure 6. - Continued. 


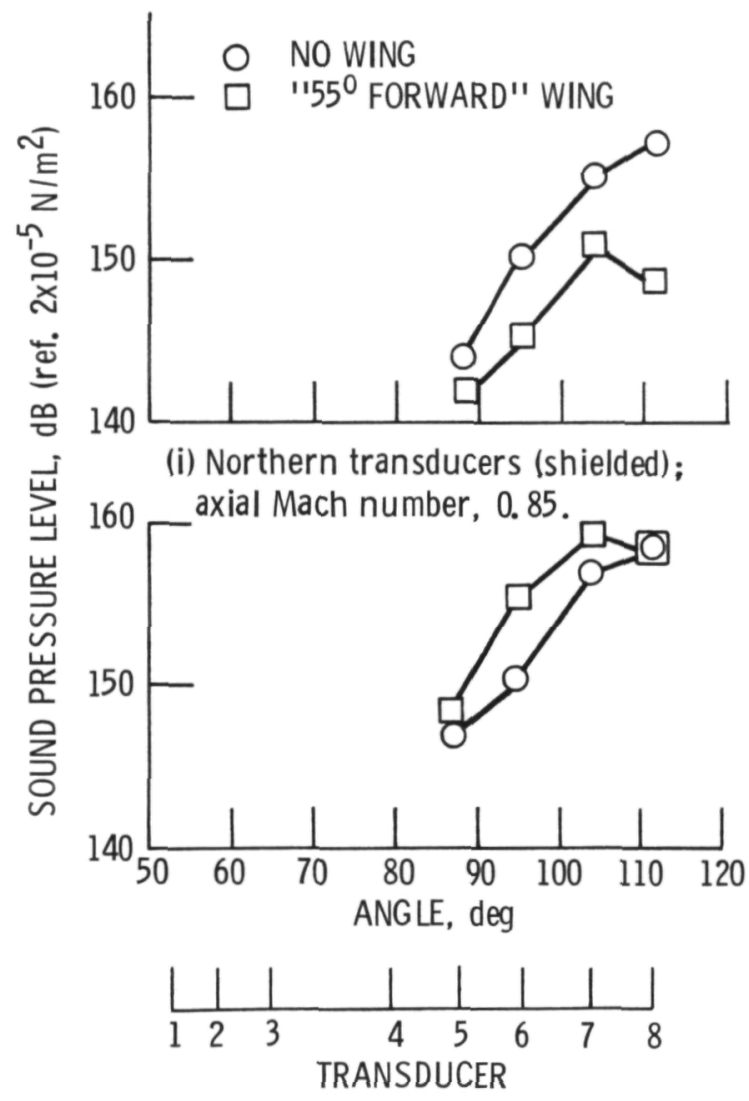

(j) Southern transducers (unshielded); axial Mach number, 0.85 .

Figure 6. - Concluded. 


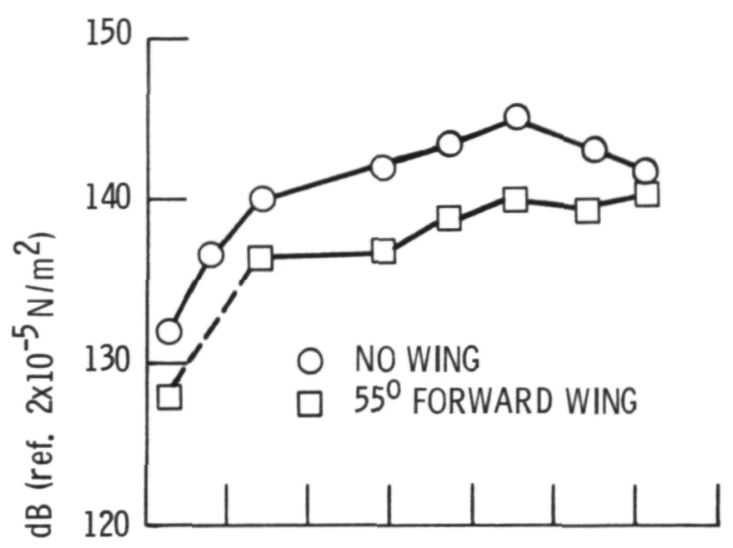

تं (a) Northern transducers (shielded);

岃

150 _ axial Mach number, 0.6.

30

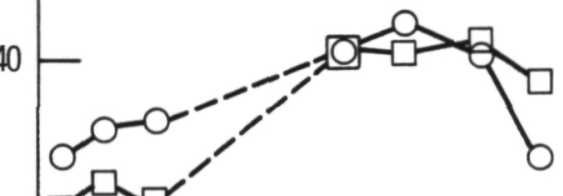

120

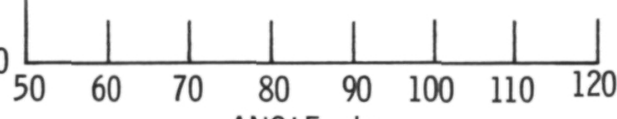
ANGLE, deg

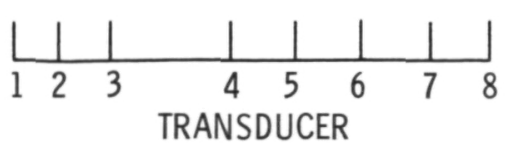

(b) Southern transducers (unshielded); axial Mach number, 0.6 .

Figure 7. - Blade passing tone sound pressure level versus position for SR-3 propellor. 


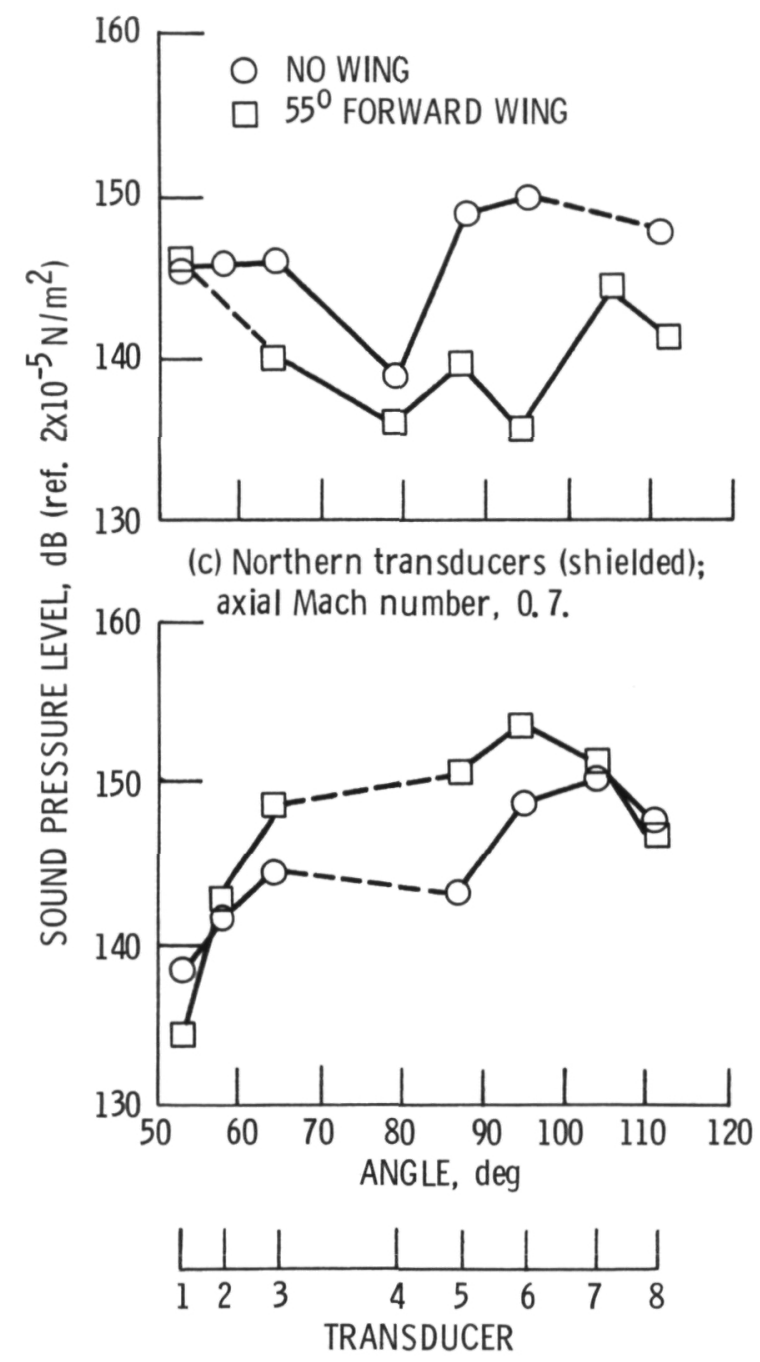

(d) Southern transducers (unshielded); axial Mach number, 0.7.

Figure 7. - Continued. 

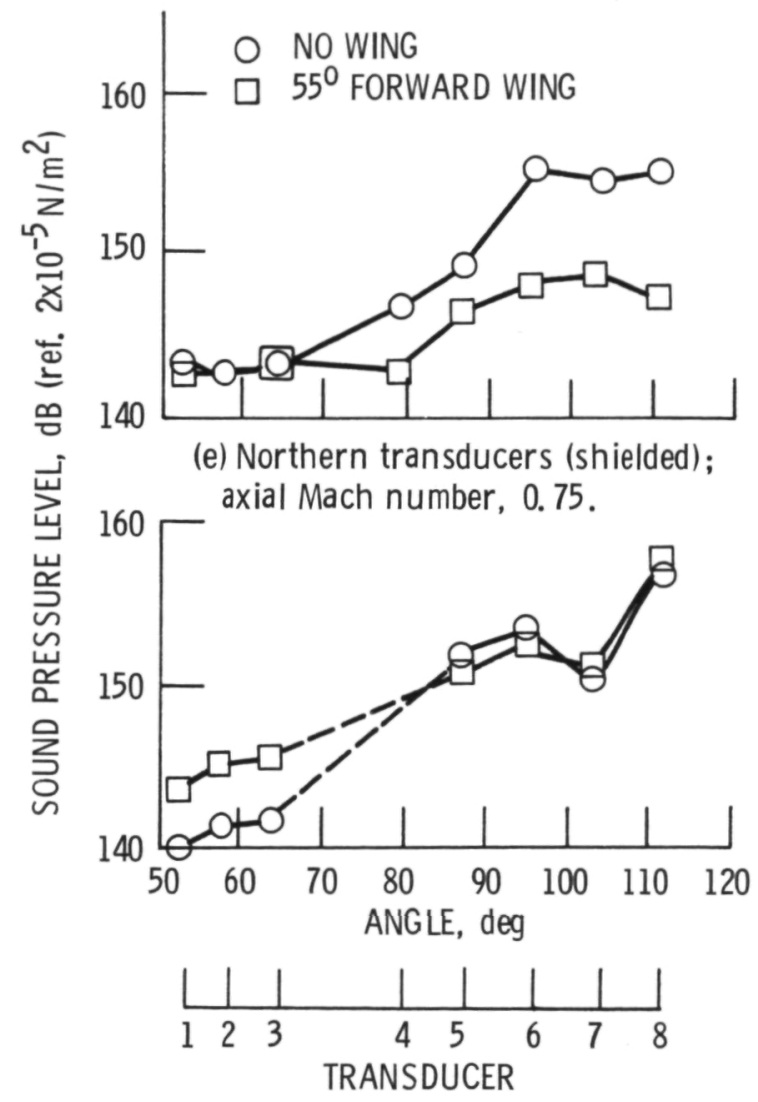

(f) Southern transducers (unshielded); axial Mach number, 0.75 .

Figure 7. - Continued. 


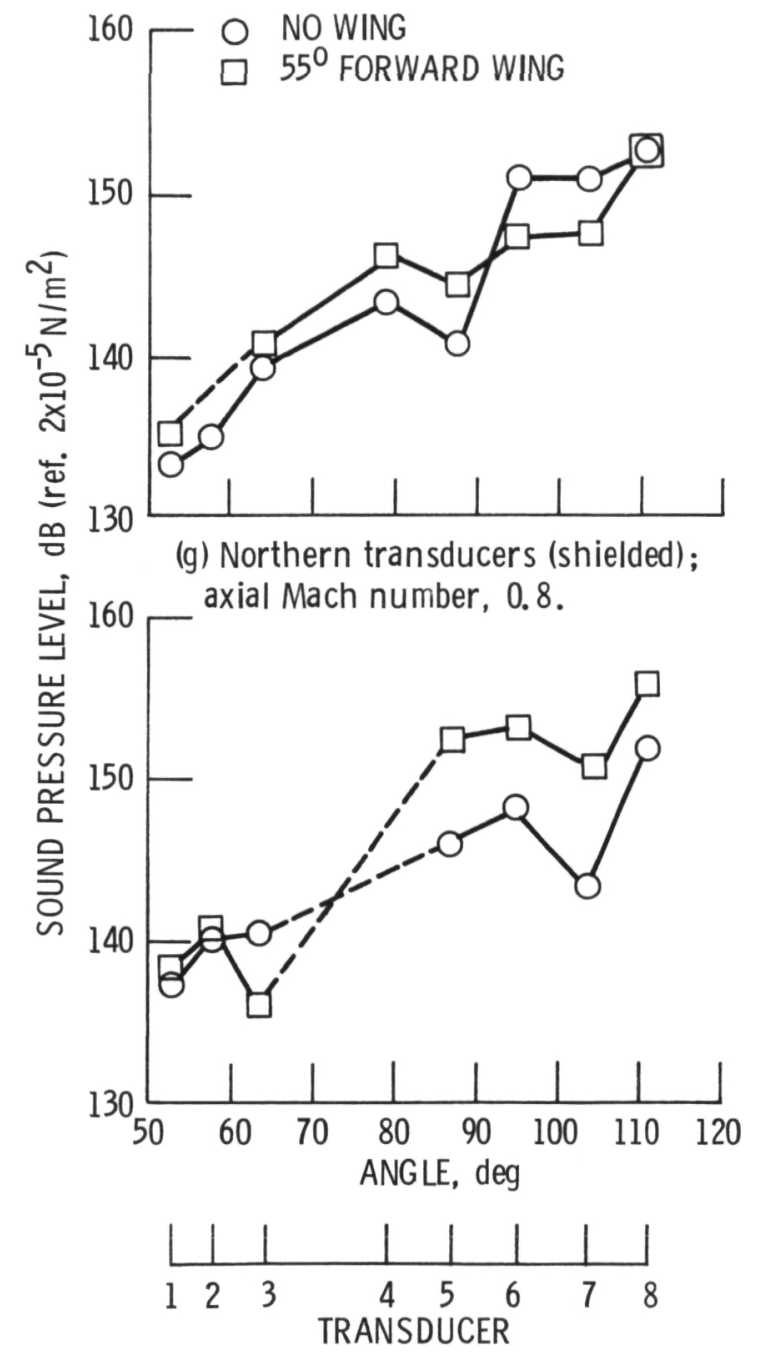

(h) Southern transducers (unshielded); axial Mach number, 0.8.

Figure 7. - Continued. 


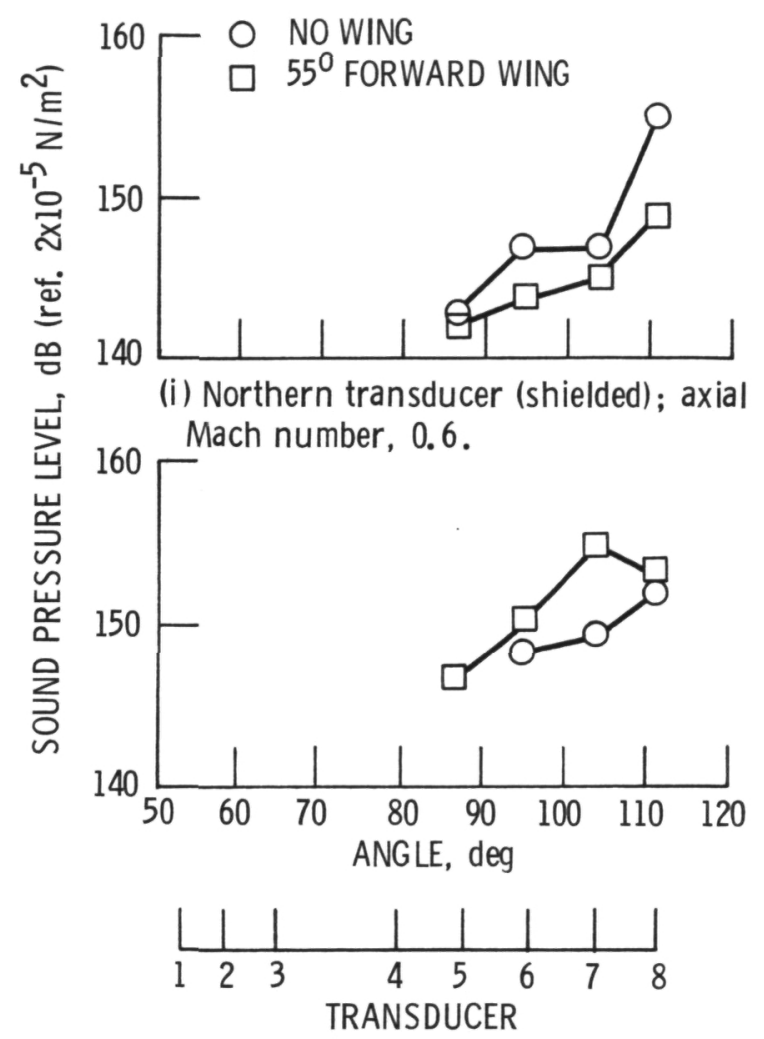

(j) Southern transducers (unshielded); axial Mach number, 0.85.

Figure 7. - Concluded. 


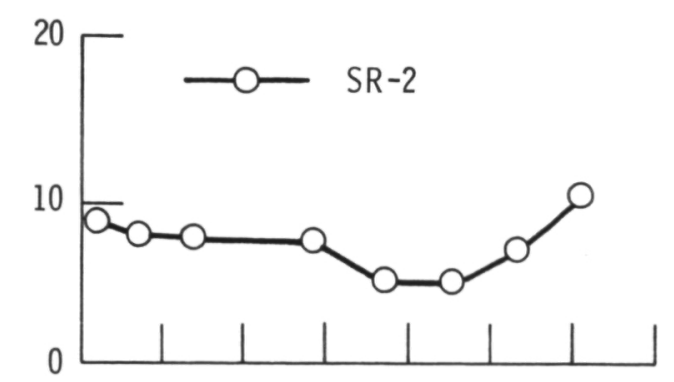

(a) Axial Mach number, 0.6.

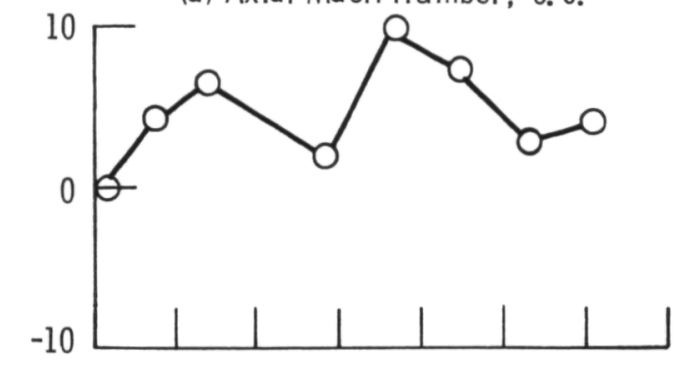

(b) Axial Mach number, 0.7.

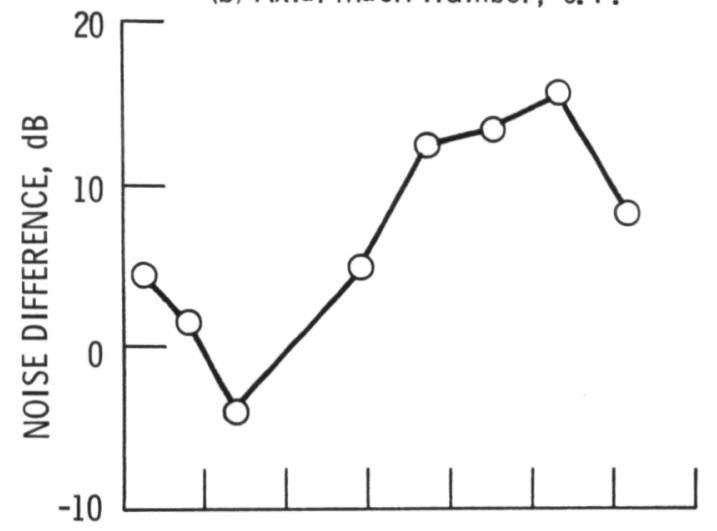

(c) Axial Mach number, 0.75 .

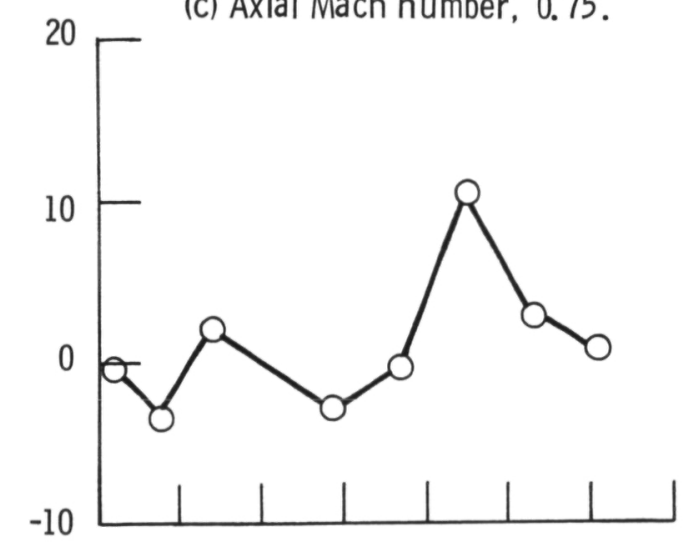

(d) Axial Mach number, 0.80 .

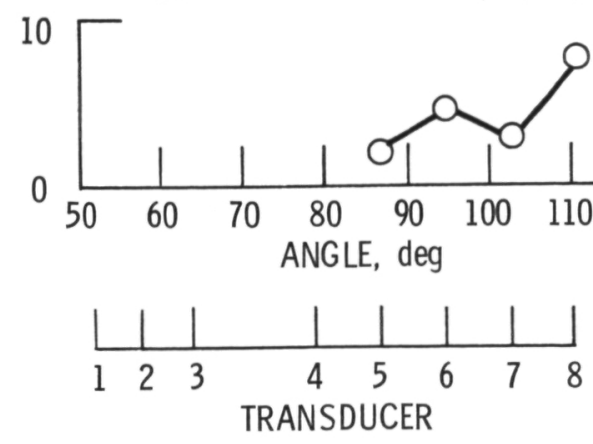

(e) Axial Mach number, 0.85 .

Figure 8. - Noise difference between nowing and wing data for SR $-2,55^{\circ}$ forward wing. 

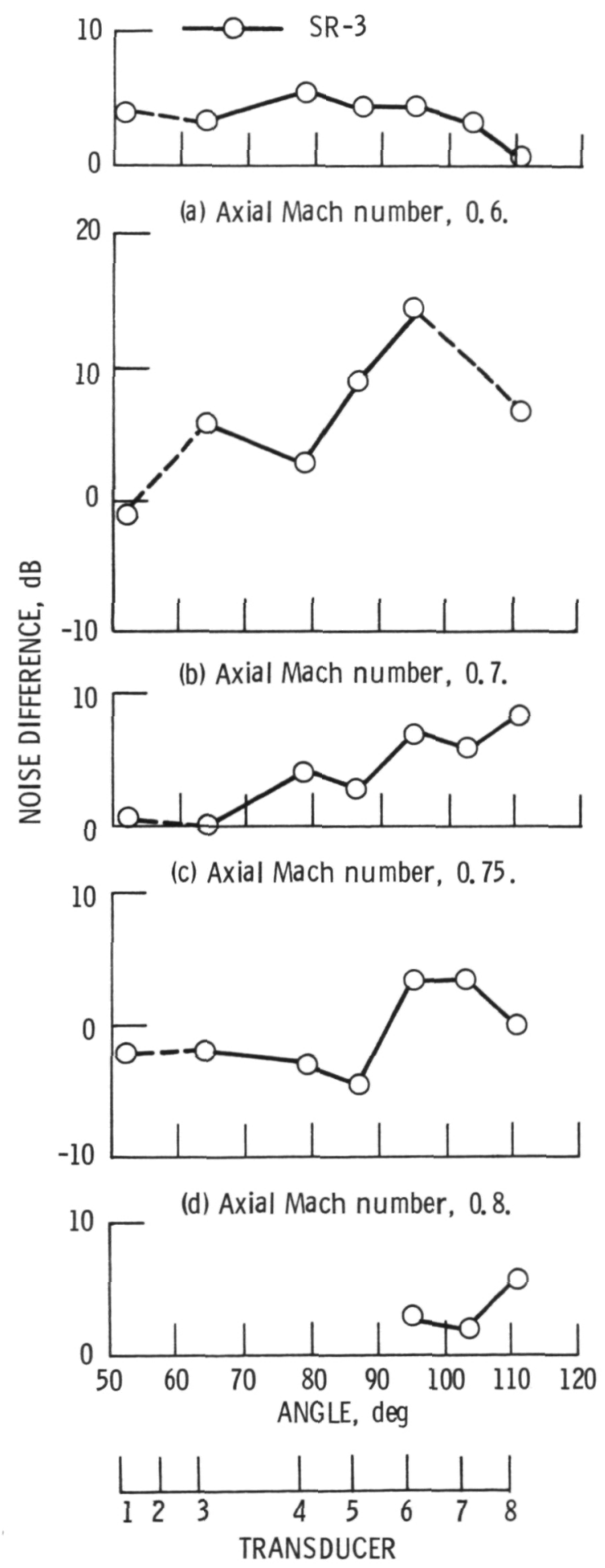

(e) Axial Mach number, 0.85 .

Figure 9. - Noise difference between nowing and wing data for SR-3, $55^{\circ}$-forward wing. 


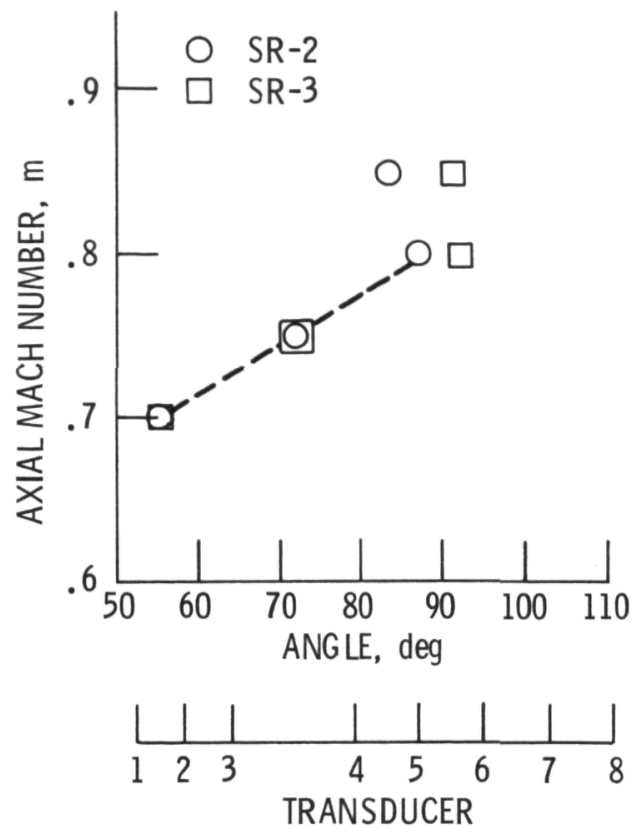

Figure 10. - Position where shielding starts.

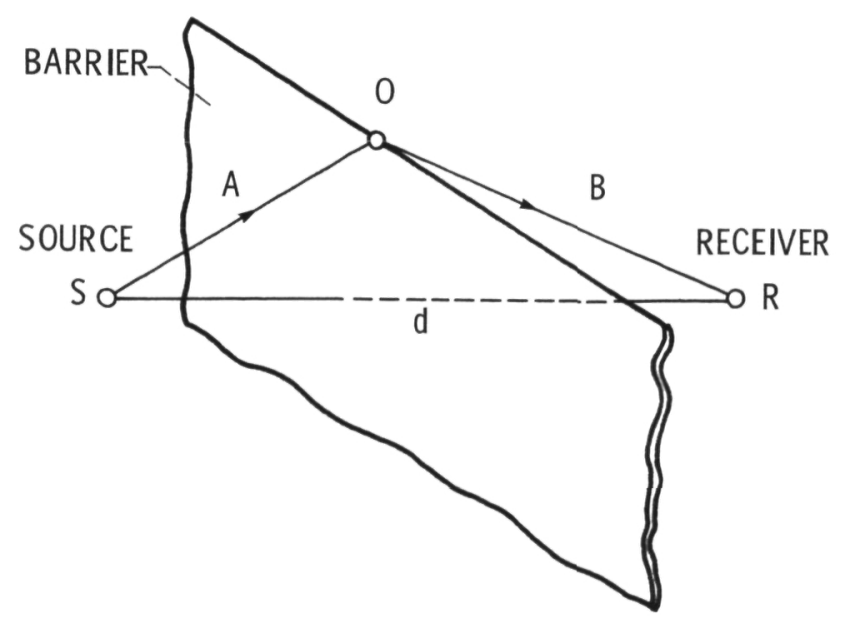

Figure 11. - Barrier geometry. 


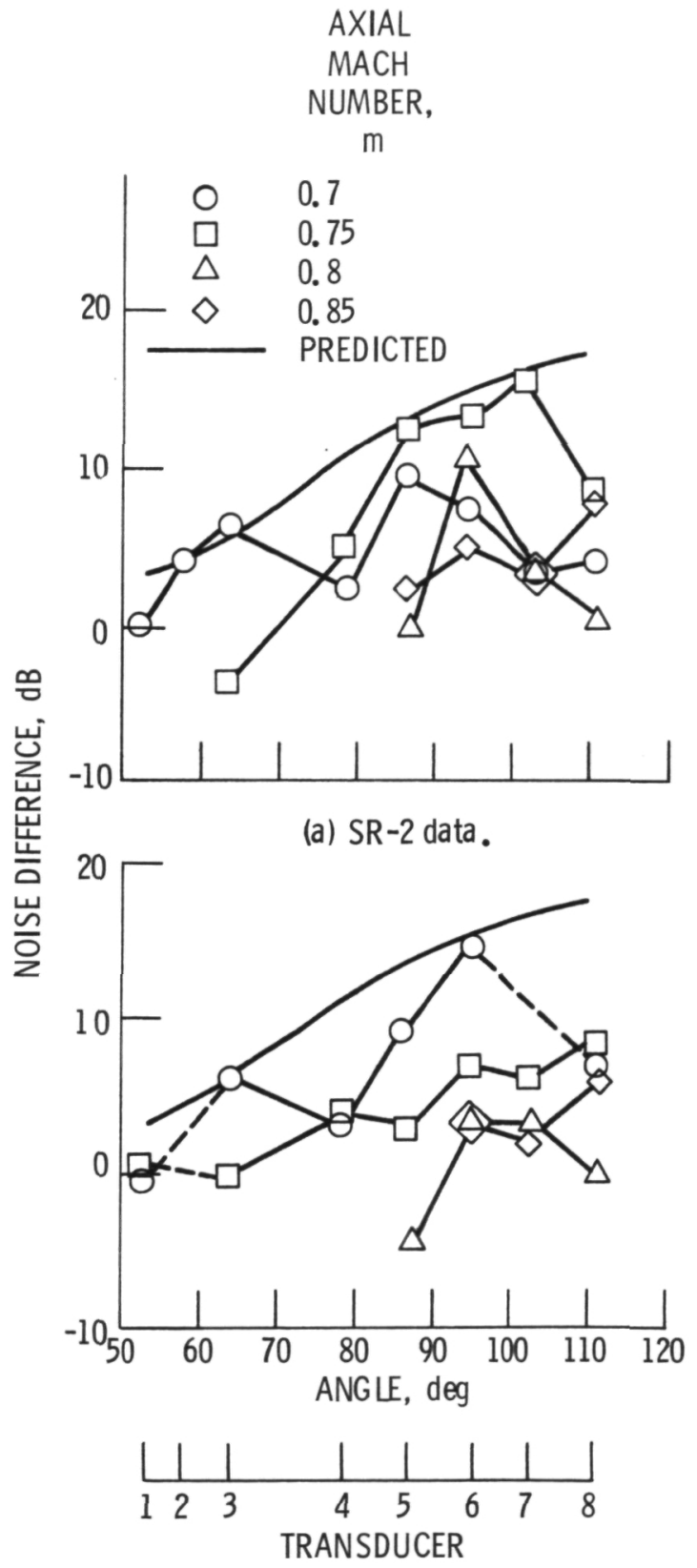

(b) SR-3 data.

Figure 12. - Comparison of measured shielding with barrier estimate. 


\section{ORIGINAL PAGE IS \\ OF POOR QUALTY}

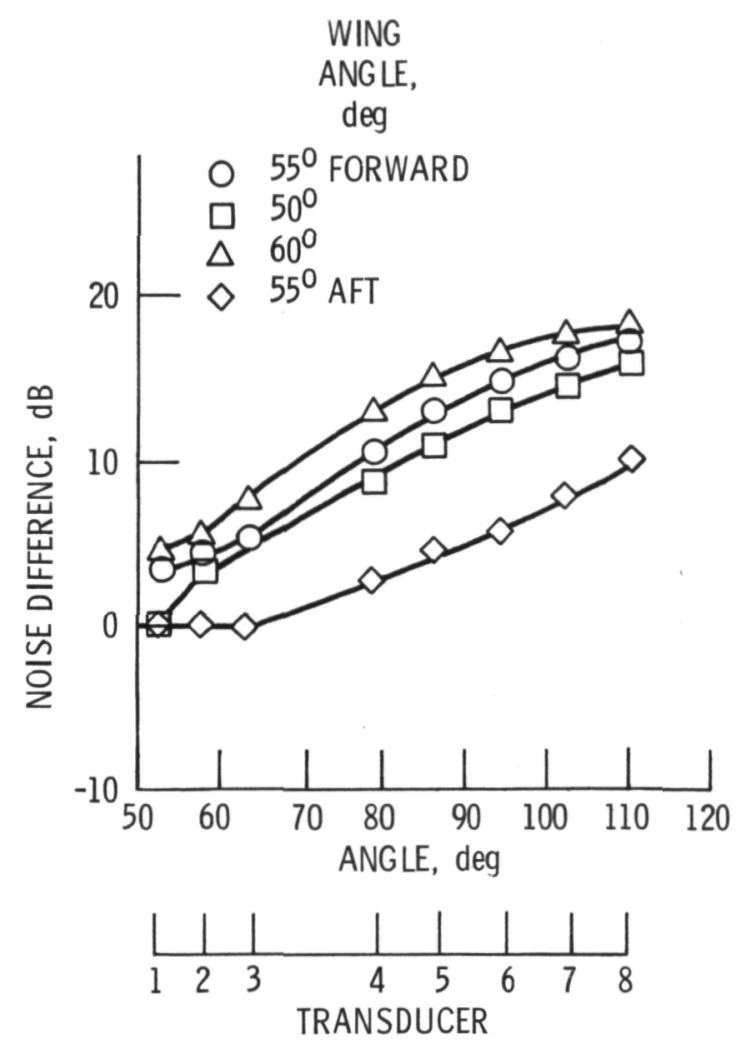

Figure 13. - Barrier shielding estimates noise difference between no-wing and wing data. 

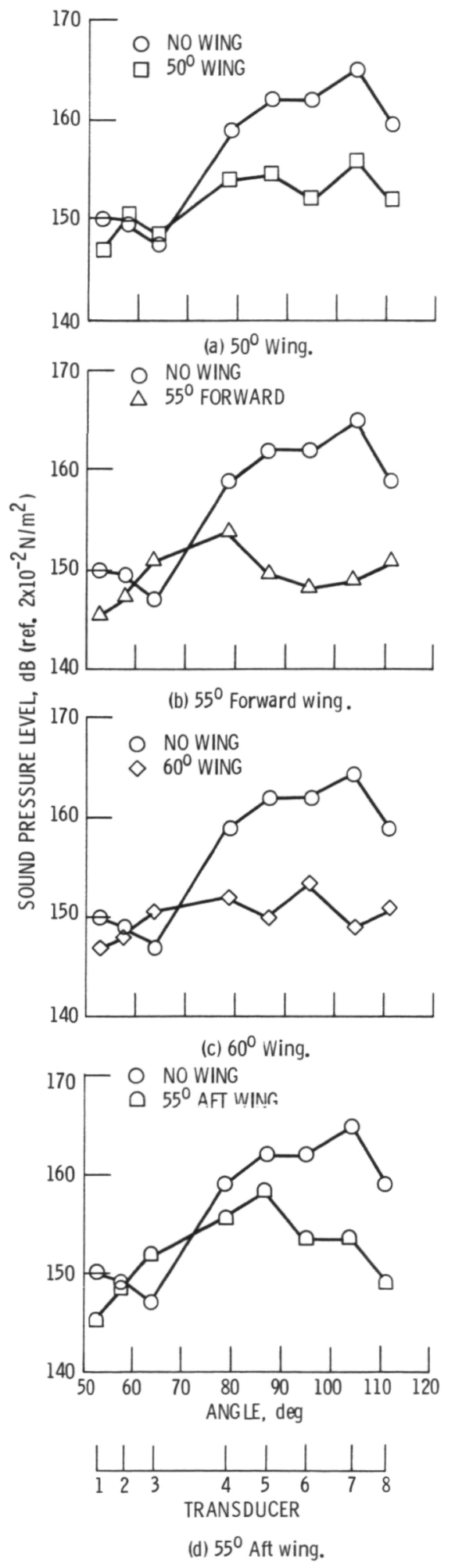

Figure 14. - Wing shielding for different wings, $S R-2$ propeller at $M=0.75$. 

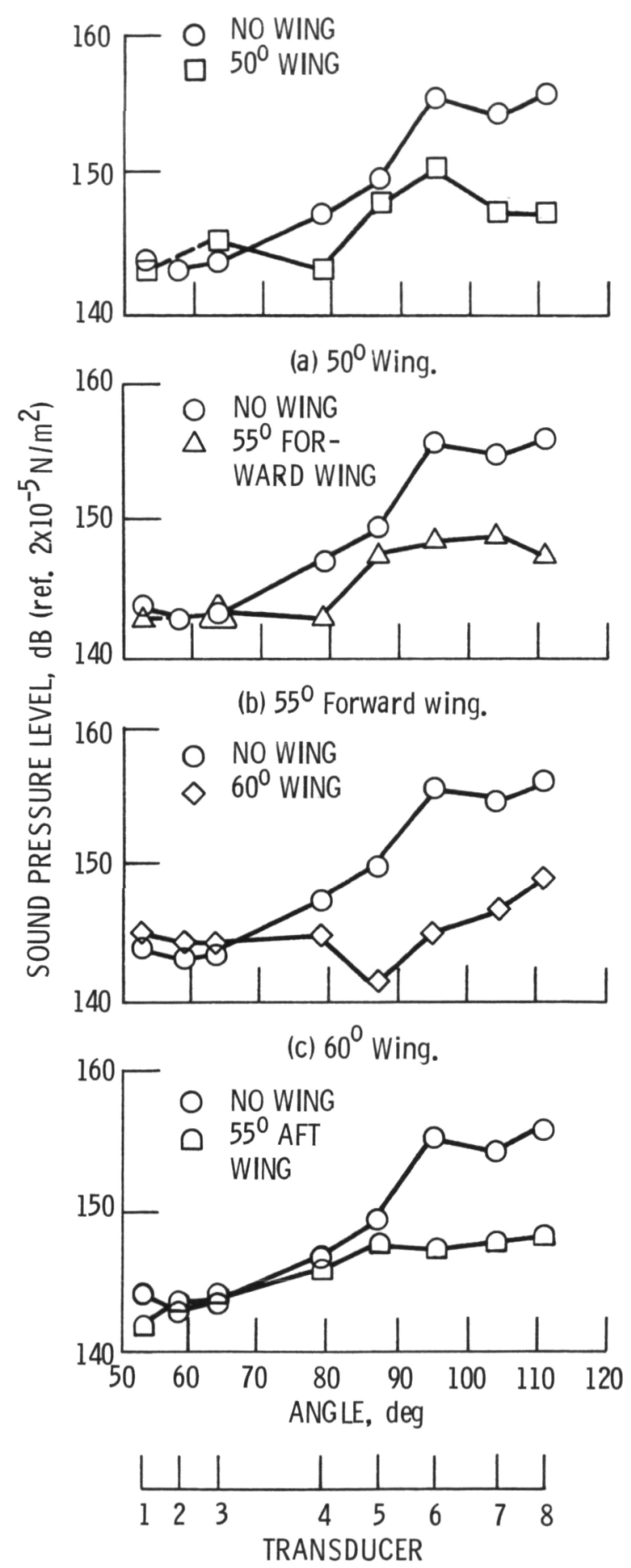

(d) $55^{\circ}$ Aft wing.

Figure 15. - Wing shielding for different wings, $S R-3$ propeller at $M=0.75$. 


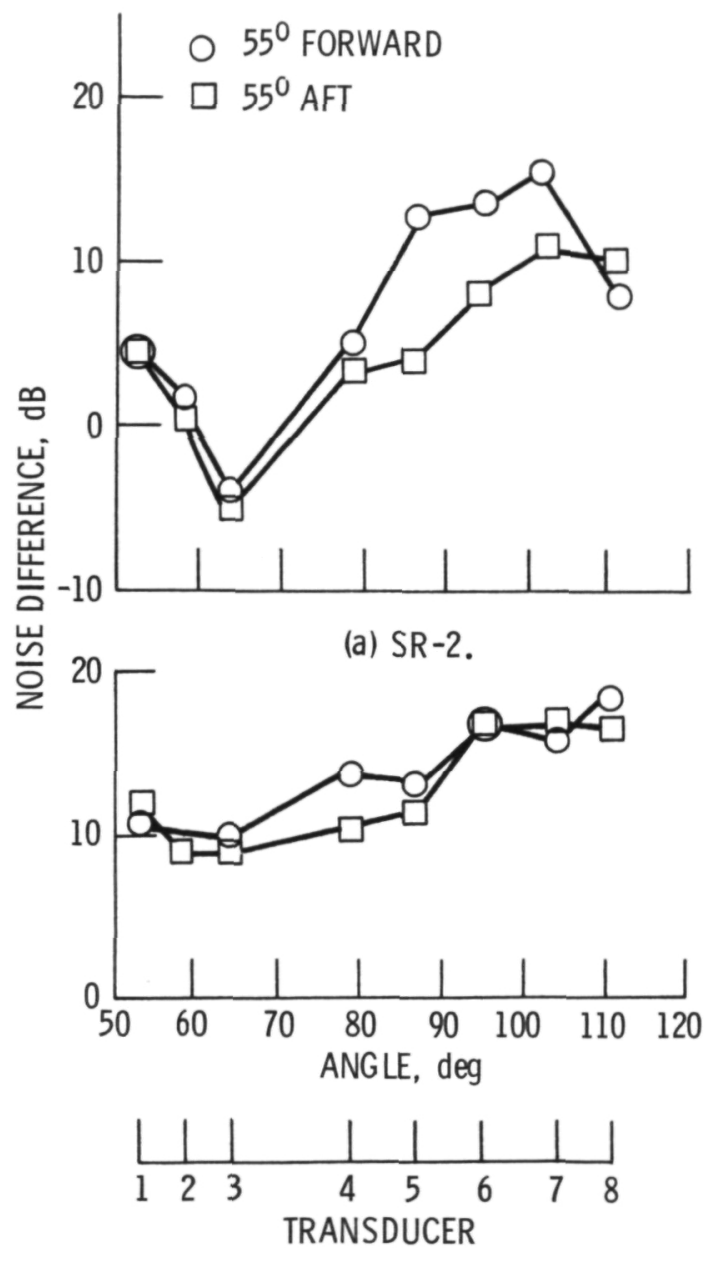

(b) SR-3.

Figure 16. - Comparison of $55^{\circ}$ Forward and $55^{\circ}$ Aft wing shielding at $M=0.75$. 


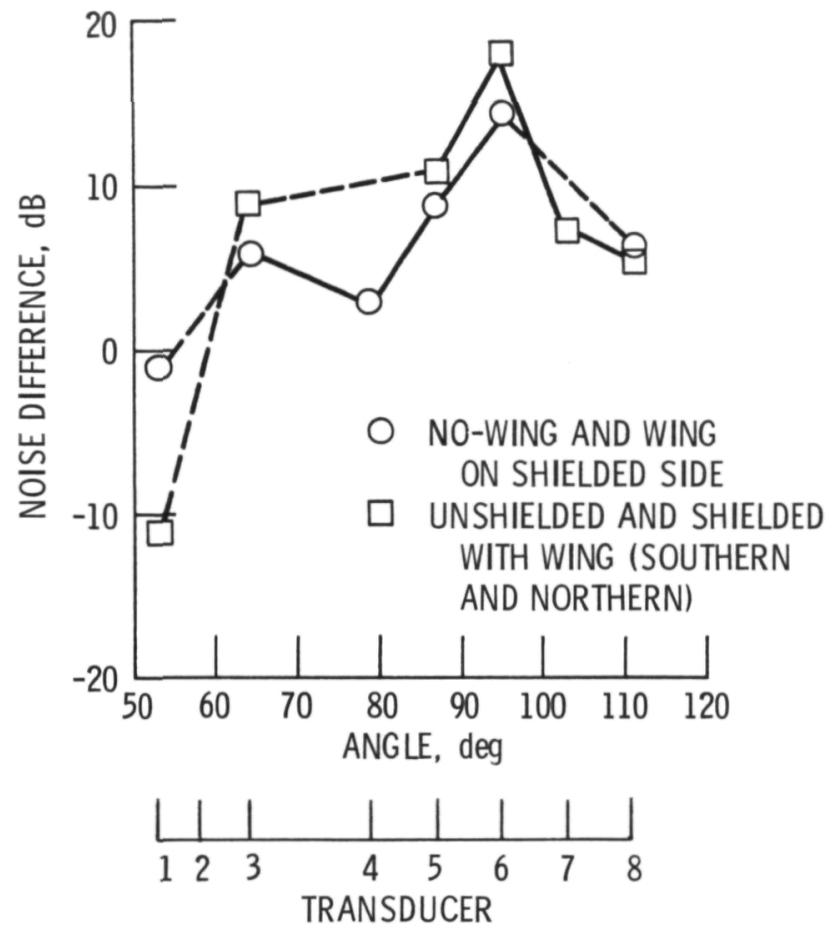

Figure 17. - Unshielded and shielded differences compared with no-wing wing differences for SR-3 propeller at $M=0.70$ with $55^{\circ}$ forward wing. 


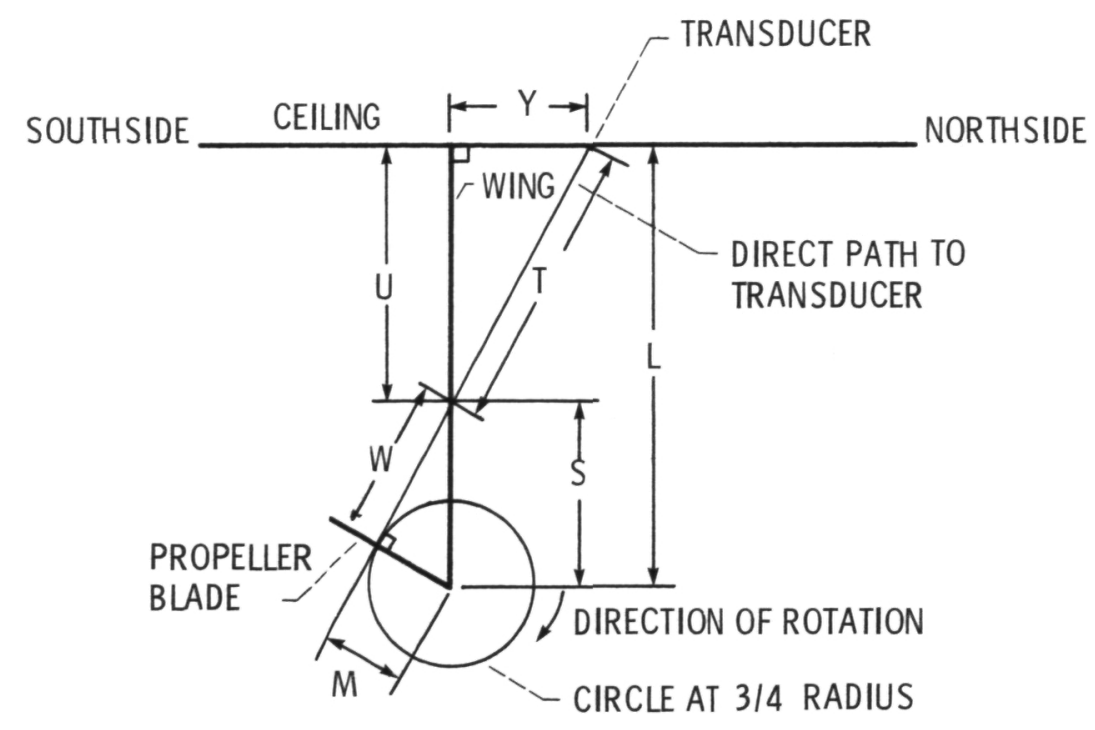

(a) Front view of propeller.

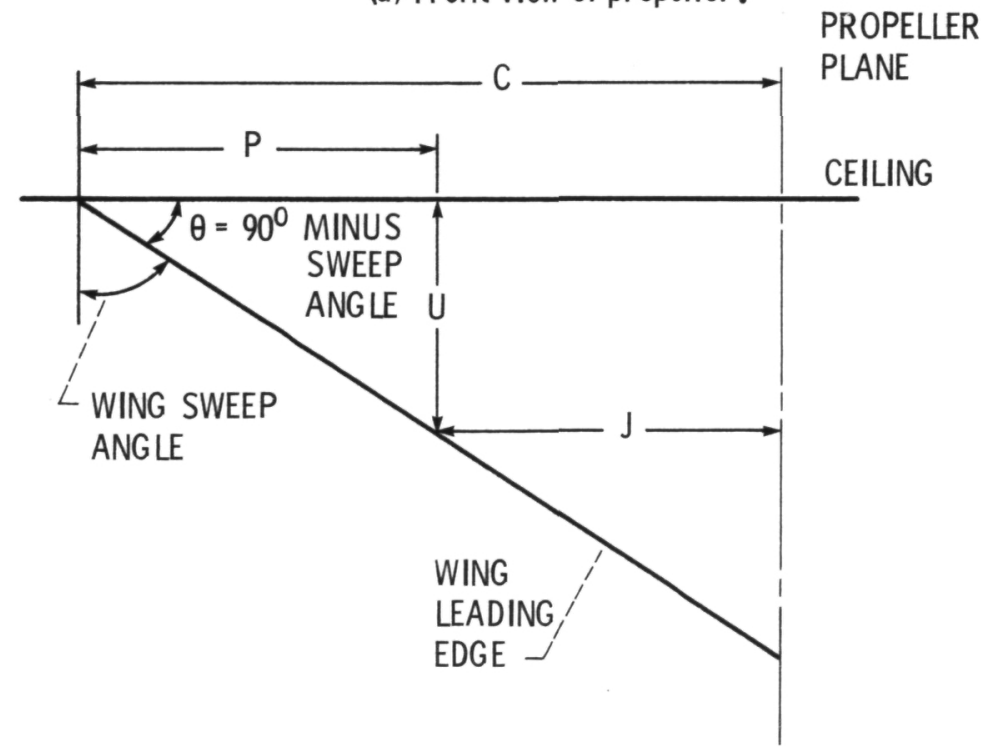

(b) Sideview.

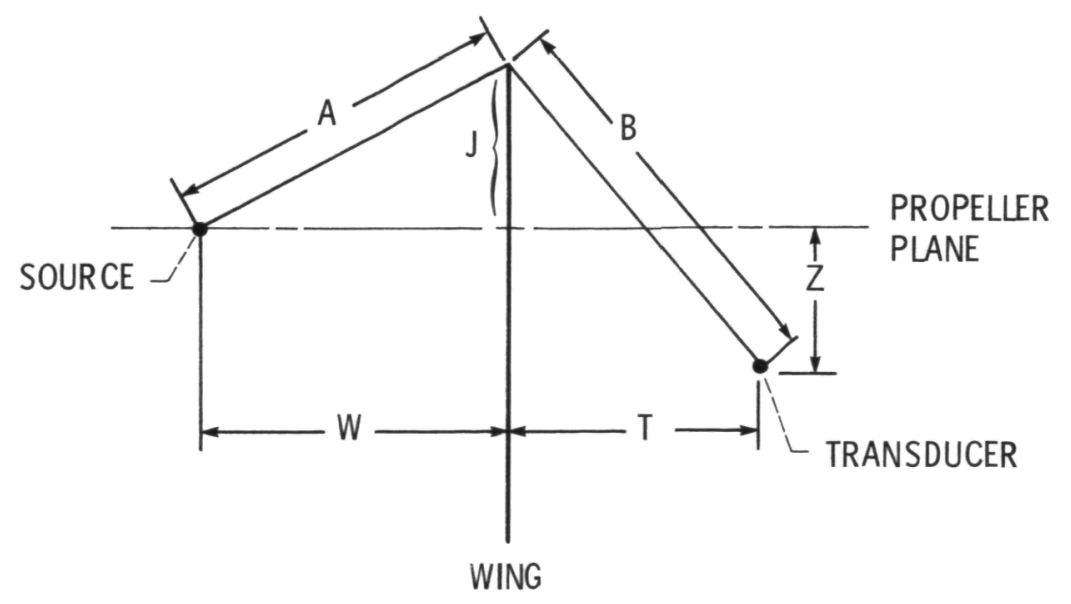

(c) Diffracted path around wing (topview).

Figure 18. Geometry of the wing and propeller experiment. 


\begin{tabular}{|c|c|c|c|}
\hline $\begin{array}{l}\text { 1. Report No. } \\
\text { NASA TM- } 87112\end{array}$ & 2. Government Accession No & \multicolumn{2}{|c|}{3 Recipient's Catalog No. } \\
\hline \multicolumn{2}{|c|}{$\begin{array}{l}\text { 4. Title and Subtitle } \\
\text { An Experimental Investigation of Reducing Advanced } \\
\text { Turboprop Cabin Noise by Wing Shielding }\end{array}$} & \multicolumn{2}{|l|}{ 5. Report Date } \\
\hline \multirow{2}{*}{\multicolumn{2}{|c|}{$\begin{array}{l}\text { 7. Author(s) } \\
\text { James H. Dittmar }\end{array}$}} & \multicolumn{2}{|c|}{$\begin{array}{l}\text { 8. Performing Organization Report No. } \\
\text { E-2713 }\end{array}$} \\
\hline & & \multicolumn{2}{|l|}{ 10. Work Unit No. } \\
\hline \multicolumn{2}{|c|}{$\begin{array}{l}\text { 9. Performing Organization Name and Address } \\
\text { National Aeronautics and Space Administration } \\
\text { Lewis Research Center } \\
\text { Cleveland, Ohio } 44135\end{array}$} & \multicolumn{2}{|c|}{ 11. Contract or Grant No. } \\
\hline \multicolumn{2}{|c|}{$\begin{array}{l}\text { 12. Sponsoring Agency Name and Address } \\
\text { National Aeronautics and Space Administration } \\
\text { Washington, D.C. } 20546\end{array}$} & \multicolumn{2}{|c|}{ 14. Sponsoring Agency Code } \\
\hline \multicolumn{4}{|c|}{$\begin{array}{l}\text { 15. Supplementary Notes } \\
\text { Prepared for the Tenth Aeroacoustics Conference sponsored by the American } \\
\text { Institute of Aeronautics and Astronautics, Seattle, Washington, July 9-11, } 1986 \text {. }\end{array}$} \\
\hline \multicolumn{4}{|c|}{$\begin{array}{l}\text { 16. Abstract } \\
\text { An experimental investigation was undertaken to determine if wing shielding could } \\
\text { reduce the noise impacting the fuselage of an advanced turboprop airplane. Four } \\
\text { wings were tested behind two eight-bladed propeller models. Significant shield- } \\
\text { ing of the propeller noise was observed and a particular wing-propeller geometry } \\
\text { was identified to provide the most shielding. Specifically, an up-inboard rota- } \\
\text { tion would be needed for a low-wing airplane and a down-inboard rotation for a } \\
\text { high-wing airplane. As the axial Mach number was increased, the position where } \\
\text { the shielding starts moved farther downstream. This shift in the start of } \\
\text { shielding was roughly a straight line with respect to Mach number between } \\
\text { M=0.7 and M =0.8. At M } 0.85 \text { the start of shielding does not shift any } \\
\text { farther downstream. A simple barrier noise-reduction model gave the same trends } \\
\text { with transducer position as did the data, and, if corrected for Mach number } \\
\text { shift, the model might be used to provide estimates of the wing shielding. } \\
\text { Besides providing a barrier to the noise reaching the shielded area, the wing } \\
\text { also reflects some of the noise back onto the unshielded area. This can make } \\
\text { the noise difference between the unshielded and shielded areas of the fuselage } \\
\text { larger than would be expected by simple wing shielding. }\end{array}$} \\
\hline $\begin{array}{l}17 \text { Key Words (Suggested by Auth } \\
\text { Propeller noise } \\
\text { Noise } \\
\text { Wing shielding }\end{array}$ & $\begin{array}{l}\text { 18. Distributio } \\
\text { Unc lass } \\
\text { STAR Ca }\end{array}$ & $\begin{array}{l}\text { ent } \\
\text { y } 71\end{array}$ & \\
\hline $\begin{array}{l}\text { 19. Security Classif. (of this report) } \\
\text { Unc lass if ied }\end{array}$ & $\begin{array}{l}\text { Security Classif. (of this page) } \\
\text { Unc lass if i ed }\end{array}$ & 21. No. of pages & 22. Price* \\
\hline
\end{tabular}

${ }^{\star}$ For sale by the National Technical Information Service, Springfield, Virginia 22161 
National Aeronautics and

Space Administration

Lewis Research Center

Cleveland. Ohio 44135

Official Business

Penalty for Private Use $\$ \mathbf{3 0 0}$
SECOND CLASS MAIL

ADDRESS CORRECTION REQUESTED

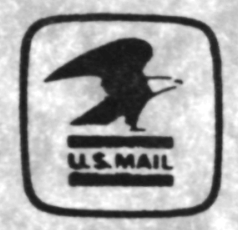

Postage and Fees Paid National Aeronautics and Space Administration NASA-451 